\title{
«Cual doctora en cielo graduada... ». La poesia femenina per als certàmens literaris amb motiu de la beatificació i canonització de Teresa de Jesús (València, 1614 i 1621; Barcelona, 1614)
}

\author{
«Cual doctora en cielo graduada... ». The feminine poetry for literary contests in \\ honor of the beatification and canonization of Teresa of Ávila (València, 1614 i 1621; \\ Barcelona, 1614)
}

\author{
Verònica Zaragoza Gómez \\ veronica.zarago@gmail.com \\ Univseritat de Girona - Universitat Oberta de Catalunya
}

\begin{abstract}
Resum: L'objectiu d'aquest estudi és examinar les composicions poètiques aportades per dones als tres certàmens celebrats a València i Barcelona, amb motiu de la beatificació (1614) i posterior canonització (1622) de Teresa de Jesús; dos moments clau per a la consolidació de la fama de la carmelitana avilesa que van possibilitar l'exhibició pública i impressió de poesia femenina. Analitzem també la participació femenina catalana al certamen celebrat a Saragossa el 1614 per la beatificació. L'estudi està enfocat des d'una perspectiva femenina, a través de la revisió de dihuit poesies amb signatura de dones que ens han transmès les extenses relacions impreses. Al llarg del comentari dels poemes, analitzem la percepció general que aquestes dones tenen de Teresa de Jesús y ens centrem en algunes de les imatges tòpiques sobre la vida i l'obra de la fundadora. Incidim en la documentació biogràfica de les autores, setze poetes 'de circumstàncies' conegudes tan sols per un nom i cognom(s) estampats a la rúbrica. A més, proporcionem unes breus pinzellades sobre la recepció femenina de la figura de la carmelita avilesa a l'àmbit lingüístic català.
\end{abstract}

Paraules clau: poesia femenina; poesia de certamen; festes barroques; Teresa de Jesús

\begin{abstract}
The aim of this study is to examine the poetic compositions made by women in the three contests held in Valencia and Barcelona on the occasion of the beatification (1614) and subsequent canonization (1622) of Teresa of Jesus; two special moments for the consoli-dation of the fame of the Carmelite nun which allowed the public display and then its printing of feminine poetry. We also analyze the Catalan female participation in the con-test held in Zaragoza in 1614 for the beatification. The study is focused from a female perspective, through the review of eighteen poems signed by women which arrived to us through extensive printed relations. Throughout the commentary of the poems, we analyze the general perception that these women have about Teresa of Jesus and we focus on some of the topical images on the life and work of the founder. We affect the bio-graphical documentation of the authors, sixteen poets 'circumstances' known only by na-me and surname (s) printed in the section. We also provide some brief touches on women's perception of the Carmelite nun from Avila figure in the Catalan language area.
\end{abstract}

Keywords: femenine poetry, contests poetry, baroque festivals, Teresa of Ávila

DATA PRESENTACIÓ: 09/12/2015 ACCEPTACIÓ: 15/12/2015 ·PUBLICACIÓ: 26/12/2015

SCRIPTA, Revista internacional de literatura i cultura medieval i moderna, núm. 6 / desembre 2015 / pp. 251 - 290 ISSN: 2340-4841 · doi:10.7203/SCRIPTA.6.7832 
Verònica Zaragoza Gómez. «Cual doctora en cielo graduada... ». La poesia femenina per als certàmens literaris amb motiu de la beatificació i canonització de Teresa de Jesús (València, 1614 i 1621; Barcelona, 1614)

\section{Notes preliminars. A propòsit de la recepció primerenca de l'obra teresiana a l'àmbit català: les petjades femenines}

La personalitat i l'obra de Teresa de Jesús han merescut al llarg del temps l'atenció d'un bon nombre d'estudiosos i estudioses. Quant a la recepció d'aquesta figura als territoris de parla catalana, malgrat la intensa activitat desenvolupada en el darrer any ${ }^{1}$ amb motiu del $\mathrm{V}$ centenari del seu naixement (prova de la qual ha resultat aquest monogràfic), certament, resta encara per fer un estudi aprofundit que determine els graus d'influència de la carmelita avilesa en les autores catalanes dels segles XVI-XVIII; aspecte que ha aportat dades interessants en relació a les autores de l'àmbit castellà, especialment des de la revisió del gènere de les Vides espirituals (Herpoel 1999). Tanmateix, l'autoritat literària que la carmelita fundadora irradia vers les nostres escriptores és inqüestionable: s'infereix d'algunes mencions i de nombroses construccions retoricoestilístiques presents en les obres de religioses exhumades en aquests territoris; però ho verifiquem, especialment, a partir de l'evolució del fenomen de l'escriptura femenina a l'esfera catalana, que progressa en paral lel a la legitimació eclesiàstica i, encara, civil, de la paraula i vida de Teresa de Jesús que des de la seva mort, cristal litzarà al segle XVII. Així, el nombre reduit d'escriptores que documentem a les acaballes del segle XVI, dóna pas a una proliferació considerable de noms de dones que es dediquen a l'escriptura: escriptores sobretot de poesia, biografies, autobiografies o Vides espirituals que haurien pouat de la vasta obra teresiana la retòrica de les metàfores i dels dobles sentits, les imatges espirituals i femenines que legitimaven la seva ploma i expressió literàries.

La carmelita descalça, la vida i obra de la qual compta actualment amb una bibliografia ingent, fou autora de poesies, obres de caràcter místic i exegètic (Camino de perfección, El Castillo interior...), autobiogràfic (Libro de la Vida), així com d'altres textos destinats a les seves filles espirituals, motivats per la creació del nou Carmel, empresa per ella mateixa: el Libro de las relaciones; el Libro de las fundaciones; el Libro de las constituciones; el Modo de visitar los conventos de religiosas; les Exclamaciones del alma a su Dios; les Meditaciones sobre los cantares; la Visita de descalzas, el Desafio espiritual, el Vejamen... En morir el 1582, la fama de Teresa de Jesús com a reformadora de l'orde (o fundadora, per ser més precisos) i com a escriptora espiritual es va disparar. Hi va contribuir, sens dubte, la proliferació de les còpies manuscrites de la seva obra que circulaven sense control i, especialment, la publicació pòstuma d'aquests materials, el 1588, per iniciativa de fray Luis de León.

\footnotetext{
* Advertim que, pel que fa a la transcripció dels textos en prosa, hem respectat l'ortografia del model exceptuant-ne l'accentuació, la puntuació i l'ús de majúscules i minúscules, que han estat regularitzats seguint els criteris actuals, mentre que en l'edició de les poesies seguim els criteris del grup de recerca Prolope (Blecua \& Serés 2008).

1 Sobretot a través de la celebració de jornades, simposis i exposicions bibliogràfiques dedicats a la recepció de Teresa de Jesús en la geografia catalana, com ara les exposicions comissariades la majoria per M. Mercè Gras: Les biblioteques de Teresa de Jesús. Exposició bibliogräfica (Biblioteca Pública Episcopal del Seminari de Barcelona); Santa Teresa de Jesús en la cultura catalana (Biblioteca de Catalunya) i Teresa de Jesús «Escribo con libertad» (CRAI. Biblioteca de Lletres Universitat de Barcelona) [consulta: 10/10/2015]. També resulta interessant la revisió del bloc Castell Interior [https://castellinterior. wordpress.com/] dedicat a Santa Teresa de Jesús i els carmelites descalços a Catalunya, amb un apartat molt interessant de bibliografia i estudis fonamentals [consulta: 10/10/2015].
}

SCRIPTA, Revista internacional de literatura i cultura medieval i moderna, núm. 6 / desembre 2015 / pp. 251 - 290 ISSN: 2340-4841 · doi:10.7203/SCRIPTA.6.7832 
Verònica Zaragoza Gómez. «Cual doctora en cielo graduada... ». La poesia femenina per als certàmens literaris amb motiu de la beatificació i canonització de Teresa de Jesús (València, 1614 i 1621; Barcelona, 1614)

Amb relació a la circulació de les obres teresianes a casa nostra, no podem obviar aquí la iniciativa d'algunes figures femenines que van possibilitar-ne el seu pas pel món editorial. El procés d'edició pòstuma i de legitimació de l'obra teresiana ha estat estudiat recentment per Verònique Jude (2012), entre d'altres ${ }^{2} i$, segons recull l'estudiosa, les temptatives de publicació van començar encara en vida de Teresa de Jesús i van culminar amb l'edició del Camino de perfección i els Avisos, entre 1582-1583: tan sols uns mesos després de la mort de la carmelita avilesa, l'arquebisbe d'Évora, Teutonio de Braganza editava ambdues obres en un sol volum a partir d'una còpia base revisada per l'autora. Amb els anys, aquests tractats apareixerien a Salamanca (1585) i a València (1587), en aquest darrer lloc de la mà d'una impressora establerta a la capital del Túria: Jerònima Galés (Gregori 2012). Com a «viuda de Pedro de Huete», Galés va preparar i publicar el Tratado llamado camino de perfección que escriviópara sus monjas la madre Teresa de Jesús, adreçat a una altra dama, devota de la santa i de llinatge català il lustre: Lucrècia de Gralla i d'Hostalric, ${ }^{3}$ qui va estar casada amb Francesc de Montcada i de Cardona (Mequinensa, 1532-València, 1594), segon comte i primer marquès d'Aitona, virrei de Catalunya i, aleshores, de València (1581-1594). ${ }^{4}$ Sens dubte, el moment culminant del procés editorial de les obres teresianes va venir el 1588 amb l'edició assumida per fray Luis de León, titulada Los libros de la madre Teresa de Jesús (Salamanca: Guillermo) que contenia el Libro de la Vida, el Camino de perfección, els Avisos, les Moradas i les Exclamaciones. Entre 1588 i 1589, se'n feia una reimpressió a Barcelona en dos volums, promoguda per Jaume Cendrat i Gabriel Lloberes i, el 1606, n’apareixia una nova edició, a costa de l’impressor Rafael Nogués adreçada a «A la Madre Sor Angela Serafina, Abadessa del monesterio de monjas Capuchinas [de Barcelona]». Àngela-Margarida Serafina (Manresa, 1543-Barcelona, 1608), fou la fundadora de les caputxines a la Península Ibèrica, amb la creació del convent barceloní de Santa Margarida la Reial, al qual pertanyien les nebodes de l’impressor, Isabel i Maria Àngela Astorch, amb reconeguda fama intel lectual i mística.

En definitiva, amb aquests títols que veieren la llum pública, ${ }^{5} \mathrm{i}$ el seu carisma espiritual, a les darreries del segle XVI-principi del XVII, Teresa de Jesús es va establir com a únic paradigma d'escriptora possible, imitada per d'altres fèmines que, com ella, pretenien fer-se un lloc entre els altars i, encara, en la 'república de les lletres' (Baranda 2005: 94 i 2014: 21-24), amb l'accés barrat a les dones. Pel que fa a l'esfera conventual, van considerar Arenal \& Schlau (1989: 139) que l'acceptació pública dels escrits i de la vida de Teresa va esdevenir un estímul perquè d'altres religioses prenguessin la ploma i poguessen veure legitimada la pròpia obra. Així mateix, pel que fa a l'eclosió de l'escriptura

\footnotetext{
2 Veg. també Llamas (1972: 228-277); i Mas Arrondo (1997: 91-100).

3 Lucrècia, morta el 1599, fou filla de Francesc de Gralla i Desplà, senyor de Subirats que, a més a més, fou ambaixador a Roma i mestre racional de Catalunya, i de Jerònima d'Hostalric (Ahumada ed. 2003: 19).

4 Tratado llamado camino de perfeccion que escrivio para sus monjas la madre Teresa de Iesus. En Valencia: en casa de la viuda de Pedro de Huete...: a costa de Balthasar Simon. Recentment, la investigadora M. Mercè Gras ha dedicat una entrada al bloc Castell Interior titulada «Els llibres de Teresa de Jesús publicats a Catalunya (ss. XVI-XVIII)», en què explica els avatars d'aquestes edicions [consulta: 5/10/2015].

5 A Barcelona se'n van publicar sis edicions diferents entre els segles XVI-XVIII. Pel que fa a les edicions i la recepció de l'obra teresiana a Barcelona durant 1588-1961, lleg. Beltran Larroya (1964).
} 
Verònica Zaragoza Gómez. «Cual doctora en cielo graduada... ». La poesia femenina per als certàmens literaris amb motiu de la beatificació i canonització de Teresa de Jesús (València, 1614 i 1621; Barcelona, 1614)

de Vides espirituals en què se submergeixen les monges als convents femenins hispànics, James Amelang (2005: 157-163) va dividir el fenomen en tres etapes, iniciat més o menys a partir de la publicació de les obres teresianes:

El periodo inicial gira en gran medida, cuando no exclusivamente, entorno a santa Teresa
de Ávila (1515-1582). Luego sobrevino un largo xvi de difusión, adaptación y disvusión,
tanto en la Península como en América, de lo que podríamos llamar el modelo teresiano. A
continuación un giro lento, pero definitivo en diferente dirección introdujo un prolongado
periodo de decadencia, cuando no de desaparición, no sólo del modelo teresiano, sino de otras
tradiciones relacionadas con este discurso religioso femenino (Amelang 2005: 157-158)

Concretant-ne la cronologia, considera l'estudiós que entre els anys 1550 i 1680 es va produir una proliferació dels diaris espirituals escrits per religioses de tots els ordes i terciàries i beates, època que va venir seguida d'un decaïment del fenomen fins que desapareix a finals del segle XviII (tot i que a l'àmbit català, les monges continuen escrivint les seves Vides). En aquest sentit, els treballs de Sonja Herpoel (1999), amb el títol suggerent $A$ la zaga de Santa Teresa: autobiografias por mandato, i d'Stacey Schlau (2002) «Following Saint Teresa: Early Modern Women and Religious Authority», sobre l'influx del model teresià, han esdevingut clàssics en el camp de la literatura femenina espanyola als segles XVI-XVIII. Això demostraria com la fama de Teresa de Jesús va afavorir la visibilització d'un model positiu d'escriptora, no tan allunyat en el temps ni tan difícil d'imitar com els models llunyans plantejats fins al moment; fins al punt que N. Baranda considera que «Su ejemplo supuso un hito sin precedentes...» pel fet que va assolir la impremta (Baranda 2005: 94). Empremta que es deixa notar també al panorama de les lletres femenines catalanes, a la llum dels estudis realitzats fins ara (Zaragoza [en premsa]). Amb aquest nou model teresià, doncs, més proper i abastable, es començava a materialitzar, encara en un estat molt embrionari, la relació entre dones i escriptura.

Hi va contribuir, especialment, el reconeixement oficial del seu model de santedat i de la vàlua de la seva obra per part de les autoritats eclesiàstiques, mitjançant la seva beatificació, el 24 d'abril de 1614, i, la posterior canonització, el 12 de març de 1622. Entre les dues dates, el 1617, havia estat proclamada «Patrona y abogada [d’Espanya] después de Santiago Apóstol» a petició de les Corts i de la mà de Felip III -tema no exempt de polèmica, d'altra banda. ${ }^{6}$ Aquestes efemèrides van ser àmpliament celebrades a les terres pensinulars, amb les consegüents commemoracions urbanes multitudinàries. De fet, la conservació de relats de les festes ens permet constatar com les festes celebrades al domini català foren de les més lluïdes de la Península. També ens ha possibilitat aplegar versos femenins dedicats a la santa, amb els quals podem arribar directament al testimoni de les dones poetes coetànies a Teresa de Jesús i al sentiment que els va despertar la seva entronització. Vegem-ho.

6 Com a conseqüència del clima de tensions viscut entre 1617-1620, el patronat va quedar suspés un anys fins que va ser confirmat de nou el 1626 pel rei Felip IV; sobre aquest tema, lleg. Thompson (2008), 
Verònica Zaragoza Gómez. «Cual doctora en cielo graduada... ». La poesia femenina per als certàmens literaris amb motiu de la beatificació i canonització de Teresa de Jesús (València, 1614 i 1621; Barcelona, 1614)

\section{Els certàmens en honor a Teresa de Jesús (València i Barcelona, 1614, a la beatificació;}

\section{València, 1621): una aproximació inicial als versos femenins}

El breu pontifici promulgat el 1614 per Pau V sobre la beatificació de Teresa de Jesús va ser rebut a les terres de parla catalana amb grans demostracions d'alegria; fastuosos festejos urbans que es van veure incrementats en la seva espectacularitat per una devoció popular per la carmelita avilesa arrelada al territori. Després d'aquesta nova, la canonització no es féu esperar, promoguda per una monarquia i una jerarquia eclesiàstica contrareformistes deleroses de comptar amb nous sants en les seves files: el 1622, l'entronització als altars de la carmelita descalça, amb un edicte de Gregori $\mathrm{XV}$ que la canonitzava, juntament amb els altres sants espanyols Isidre, Ignasi de Loiola i Francesc Xavier, va tornar a generar un ambient de demostracions urbanes de joia i festejos extraordinaris assumits pels agents religiosos i civils. ${ }^{7} \mathrm{El}$ caràcter propagandístic d'aquestes commemoracions religioses ${ }^{8}$ d'acord amb el desig de difusió de l'ideari contrareformista, explicaria la implicació de tots els estrats de la societat urbana en un espectacular programa que va articular diverses manifestacions artístiques i festives en una àmplia escenografia d'ostentació barroca: des de les més religioses i solemnes, com misses, processons i sermons, fins a les més populars, com ornamentacions de carrers i esglésies, processons dels carros triomfals, moixigangues, balls, desfilades i torneigs de cavallers, lluminàries, bous, estaferms.... i, finalment, certàmens poètics.

En les commemoracions en honor a Teresa de Jesús, tots els cossos socials de les grans urbs de l'àrea lingüística catalana van sumar esforços per contribuir a la celebració: els ordes religiosos hi van contribuir amb sermons i processons i el decorat d'esglésies i convents; els músics s'encarregaren d'amenitzar l'ambient amb la força dels seus instruments; la noblesa exhibí la seva riquesa a través de rics domassos visibles a les façanes dels seus palaus, a banda de participar en els torneigs amb què pretenien palesar el seu origen noble... Seguint aquesta dinàmica, els poetes hi van oferir el que millor podien aportar-hi: versos conceptuosos que havien de servir com a arquitectura efímera (coneguda com a 'poesia mural') penjats als escenaris i altars de la festa o repartits en les processons, o bé poemes que havien de ser declamats públicament i que competien per sucosos premis als certàmens poètics, ${ }^{9}$ un element central de la festa (Blanco 1986 i 1988: 38).

\footnotetext{
7 La bibliografia publicada en els darrers temps sobre festes barroques ha augmentat en els darrers anys a tot l'àmbit hispànic. Referits a l'esfera lingüística catalana, per citar només alguns estudis, per a Catalunya, lleg. El volum publicat recentment Festes $i$ celebracions. Barcelona, 1700, de grans especialistes sobre el tema. A València existeix una tradició historiogràfica especialitzada en la qüestió, veg. Pedraza (1982); i Mínguez, González \& Rodríguez (2010).

8 Sobre el tema de les festes i els certàmens a la beatificació i canonització de sants, com els que aquí comentem, veg. Vincent-Cassy (2010).

9 Albert Rossich (2003 i 2006) va situar els antecedents dels certàmens barrocs en les antigues festes de la Gaia Ciència; amb tot, Rubió en descriu l'evolució com una «solemnitat que se sostenia i es justificava amb el seu propi prestigi» i que al segle XVII «acaba per convertir-se en un número més d'un programa de festes i es combina amb tota la barroca escenografia de què aquelles s'envoltaven» (1984-1986: 121).
}

SCRIPTA, Revista internacional de literatura i cultura medieval i moderna, núm. 6 / desembre 2015 / pp. 251 - 290 ISSN: 2340-4841 · doi:10.7203/SCRIPTA.6.7832 
Verònica Zaragoza Gómez. «Cual doctora en cielo graduada... ». La poesia femenina per als certàmens literaris amb motiu de la beatificació i canonització de Teresa de Jesús (València, 1614 i 1621; Barcelona, 1614)

Coneixem amb tot tipus de detall tots els actes que van tenir lloc en aquests festejos de l'àmbit lingüístic català gràcies als llibres de festes que es van imprimir, posteriorment, amb grans tirades (Alenda y Mira 1903; Carreres Zacarés 1926; Ettinghausen 2010...). Aquestes relacions no només expliquen el desenvolupament de les festes sinó que també descriuen els certàmens literaris amb la inclusió de bona part dels poemes presentats. La convocatòria pública s'anunciava a través de cartells als quals s'havien d'acollir tots els participants atès que establien les bases del certamen: s'hi referien les característiques dels diferents asuntos, combates o certámenes, que eren les categories a les quals podien concórrer els poetes, i portaven prefixades tant la forma mètrica com la llengua literària, determinada pel tractament temàtic. En aquest aspecte cal dir que, malgrat la presència aclaparadora del castellà com a llengua literària, també se solien presentar peces en català, llatí o d'altres. En el transcurs dels concursos poètics, els versos que havien fet arribar els participants, eren recitats, entre decorats i música, en un acte solemne davant del nombrós públic assistent. Posteriorment, s'efectuava el repartiment dels premis per a cada assumpte o secció, atorgats per un jurat d'honor, a través de la sentència pública; aquesta solia anar acompanyada del vexamen, text en vers de cloenda amb marcat to jocós i burleta que solia criticar les poesies recitades o els seus autors davant l'expectació d'un poble àvid de poesia.

\section{El certàmens amb motiu de la beatificació de Teresa de Jesús (1614)}

\section{I.I. València}

Amb l'arribada del breu de beatificació de Teresa de Jesús, el 1614, els acostumats regozijos civils, celebrats a les grans ciutats de la Península, no es van fer esperar. Els recull de manera unitària fray Diego de San José, en el volum Compendio de las solenes fiestas que en toda España se hicieron en la Beatificación de N. B. M Teresa de Jesús, fundadora de la reformación de los Descalzos y Descalzas de N. S. del Carmen (Diego de San José 1615), reflex fidedigne de la pompositat i l'entusiasme amb què es va celebrar la flamant beatificació de la carmelita a l'àmbit hispànic (Manero 1999). ${ }^{10}$ Pel que fa a les terres de llengua catalana, la relació registra festes a València, Mataró, Tarragona, Lleida, Girona, Reus, Perpinyà, Tortosa i Barcelona. ${ }^{11}$ Precisament, una de les primeres ciutats a venerar Teresa de Jesús com a santa fou València. En el volum de San José, a través d'una carta enviada pel prior del

10 La primera part està dedicada a descriure les festes de Madrid, amb una narració ben extensa i molts poemes (fins f. 62), mentre que la segona, amb paginació nova, va dedicada a la resta de ciutats hispàniques: «Parte segunda de las fiestas que se celebraron en los conventos de religiosos y religiosas carmelitas descalços de toda España», amb el subtítol: «Relaciones que se embiaron de muchas ciudades y villas de España, en que se contiene la suma de las solenísimas fiestas que se hicieron en la beatificación de nuestra Madre Teresa de Jesús».

11 Ens consta que M. Mercè Gras està estudiant algunes notes manuscrites referides a les festes de Barcelona, Tarragona, Perpinyà i Tortosa; veg. p. e. l'entrada al bloc Castell interior «Teresa de Jesús i els cavallers catalans: un relat en català del torneig de les festes de beatificació (1614)» [consulta: 10/10/2015]. 
Verònica Zaragoza Gómez. «Cual doctora en cielo graduada... ». La poesia femenina per als certàmens literaris amb motiu de la beatificació i canonització de Teresa de Jesús (València, 1614 i 1621; Barcelona, 1614)

convent del Carme de València, llegim els actes que van tenir lloc a la capital del Túria en què es van implicar les autoritats de la ciutat, ${ }^{12}$ amb la imbricació d'elements populars i religiosos: processons, sermons, lluminàries, poesia mural, música..., i un concorregut concurs poètic obert a la participació, que va donar termini als festejos amb gran expectació popular (Diego de San José 1615: f. 44-49v). ${ }^{13}$ Tot i que hi degué acollir plomes valencianes ben reconegudes, no podem saber res més que el que va explica el prior carmelità sobre aquesta «honesta recreación». ${ }^{14}$ Per la brevetat de l'epístola transcrita per Diego de San José, tan sols ens han arribat les peces de sor Jacinta Herèdia (?), ${ }^{15}$ Gaspar Bàrbara i Àlvaro Vique, però no la sentència ni la introducció. Ara bé, més enllà de la participació de sor Jacinta (de qui no comptem amb cap dada biogràfica), podem intuir una major presència femenina si tenim presents les dades que proporciona M. Carmen Marín (2013 i [en premsa]) sobre la implicació de les dones al certamen celebrat a Saragossa aqueix mateix any, per la mateixa efemèride. Siga com siga, és interessant que ens detinguem en la cançó que sor Jacinta aporta a l'ocasió, ja que explora la devoció coneguda de Teresa de Jesús per sant Josep, a través del recurs d'un rica imatgeria marítima. ${ }^{16}$ Val la pena que ens hi detinguem un moment, a partir dels versos inicials:

Salió el navío de Teresa santa
sulcando los profundos y anchos mares
deste mundo con próspera bonanza.
De virtudes, riquezas a millares
cargó con abundancia y copia tanta
que fue toda su gloria y buena andanza.
Bien logró su esperanza
pues, arribando al puerto
del bien divino y cierto,
se halló con tal ganancia y tal tesoro
que hasta el supremo y levantado coro,
que de tanta grandeza es bien se asombre,
con inmortal decoro
sube la fama de su altivo nombre.

12 Vicent J. Escartí ha dedicat una entrada a Castell Interior per explicar aquests festejos valencians: «Festes valencianes a santa Teresa (1614 i 1622)» [consulta: 10/10/2015].

13 Sobre aquest certamen, veg. la descripció de Ferrando (1983: 931); i Mas i Usó (2009: 179-183), que també transcriu les peces.

14 En notícia de la carta del prior de València: «Cada tarde avía un bien rato de honesta recreación, porque se leían los versos de las personas que los traýan por su devoción, aviendo en ellos su modo de competencia y juycio, y se davan a los más aventajados algunos pares de guantes, y se gastaron más de cien pares. Pero la última tarde fue en el mismo género de grande fiesta porque se leyeron los versos premiados y la sentencia; que assí ella como una introducción que se leyó para este acto fueron en grande manera elegantes y curiosas. Con lo cual se acabaron nuestras fiestas [...]» (cf. Diego de San José 1615: f. 46-46v).

15 No s’ha conservat cap dada biogràfica d'aquesta devota de Teresa de Jesús. Martí i Ascó (2004 [2013]: 369), considera que podria ser almenys valenciana d'adopció i Herrero ho recull (2009: 61-62), però no podem certificar que es tracte d'una valenciana o si té origen aragonès.

16 Carreres de Calatayud (1949: 268-269), ja havia fet notar aquestes imatges marítimes en aquesta composició, molt recurrents en la poesia de certàmens valencians.

SCRIPTA, Revista internacional de literatura i cultura medieval i moderna, núm. 6 / desembre 2015 / pp. 251 - 290 ISSN: 2340-4841 · doi:10.7203/SCRIPTA.6.7832 
Verònica Zaragoza Gómez. «Cual doctora en cielo graduada... ». La poesia femenina per als certàmens literaris amb motiu de la beatificació i canonització de Teresa de Jesús (València, 1614 i 1621; Barcelona, 1614)

Metafòricament, la santa pilota una nau («navío»), que és la «nave santa de su orden» que té, com la Mare de Déu («virginea barca»), per «piloto y por patrón benigno» a sant Josep (v. 29-30). Gràcies a aquest guia, Teresa pot prosperar en la creació del nou orde reformat:

$24 \quad$ Y así Teresa, que con esta guía la nave santa de su orden guía, corrió tranquila y próspera bonanza, que tal norte podía asegurar su gloria y esperanza.

Josef divino, vos que governastes de María la hermosa y bella nave y el pan que trajo desde el alto cielo

32 como divina y soberana llave, en vuestro fiel amparo le guardastes. Bien de Teresa el amoroso celo pagáis, pues, con desvelo, servís de centinela y de despierta vela en lo que os tiene santo encomendado. De su nave el timón os tiene dado $y$ en estos hechos soberanos fundo su amor tan declarado $y$, en vos, un favor raro sin segundo.

Sant Josep és vist com un guia i com la font d'inspiració de totes les empreses de la santa; per això és considerat «Santelmo» ('salvador') i «luminosa estrella» (v. 46) i «áncora firme» (v. 48), «fanal de luz» (v. 51), «carta» ('carta nàutica', v. 53), «gobernalle» ('timó per dirigir un vaixell') i «brújula» (v. 54), a través d'un lèxic relacionat amb el camp semàntic marítim:

44
Vos sois su amparo cierto, abrigo y sombra, vos a las velas de su nave bella les dais el favorable y fresco viento; vos sois Santelmo y luminosa estrella, con que borrasca alguna no le asombra; áncora firme que, en el mar violento de todo movimiento, la guarda y asegura; el fanal de luz pura que en lo más alto della resplandece, carta que mira en cuanto se le ofrece, brújula y gobernalle milagroso; $\mathrm{y}$ al fin su gloria crece con vos, Josep y su blasón famoso. 
Verònica Zaragoza Gómez. «Cual doctora en cielo graduada... ». La poesia femenina per als certàmens literaris amb motiu de la beatificació i canonització de Teresa de Jesús (València, 1614 i 1621; Barcelona, 1614)

A continuació, l'autora compara els favors rebuts per la santa, auxiliada per sant Josep, amb els elements d'un navili:

Las grandiosas mercedes y favores
con que la enriquecéis vos cada día
son el bauprés, trinquete y la mesana,
las armas y divina artillería
que la guardan en trances y rigores
de cualquier batería loca y vana.
Teresa soberana,
si en vuestra hermosa nave
tanta grandeza cabe,
con tener a Josef, si bien lo miro,
ya de su altiva gloria no me admiro
y que vos entre cándidas estrellas
de diamante y zafiro
tengáis asiento entre las luces bellas. ${ }^{17}$
$[. .].($ Diego de San José 1615: f. $46 \mathrm{v}-47 \mathrm{v})$

En relació a la temàtica central d'aquests versos cal recordar que la figura de sant Josep és prsent en l'obra de Teresa de Jesús com a intercessor en algunes de les seves experiències biogràfiques i espirituals; fou especialment a partir de la seva malaltia que va prendre «por abogado y señor al glorioso San José y encomendéme mucho a él», tal com ho explica ella mateixa al seu Libro de la Vida. ${ }^{18}$

\section{II. Barcelona}

Quant a les festes celebrades a Barcelona el mateix 1614 per la beatificació de Teresa de Jesús, van tenir lloc a l'església del convent de carmelites descalços Sant Josep, promogudes per Josep Dalmau, devot i protector del Carmel Descalç. ${ }^{19} \mathrm{El}$ mateix Dalmau es va encarregar d'escriure l'extensa relació dels festejos (Dalmau 1615), la qual, a través de tres foliacions diferents, dóna compte de l'espectacularitat de la festa presidida per la virreina i les seves filles: el tractat primer «De

17 El bauprés és un «Palo grueso, horizontal o algo inclinado, que en la proa de los barcos sirve para asegurar los estayes del trinquete, orientar los foques y algunos otros usos»; el trinquete és «1. Verga mayor que se cruza sobre el palo de proa. 2. Vela que se larga en ella. 3. Palo de proa, en las embarcaciones que tienen más de uno» i, finalment, la mesana, «1. Mástil que está más a popa en el buque de tres palos. 2. Vela que va contra este mástil envergada en un cangrejo» (DRAE).

18 La religiosa pretenia fer més extensiva la devoció al sant, per tal com confessava que: «Querría yo persuadir a todos fuesen devotos de este glorioso santo, por la gran experiencia que tengo de los bienes que alcanza de Dios; no he conocido persona que de veras le sea devota y haga particulares servicios, que no la vea más aprovechada en la virtud; porque aprovecha en gran manera a las almas que a él se encomiendan... » («CAPÍTULO 6. Trata de lo mucho que debió al Señor en darle conformidad con tan grandes trabajos, y cómo tomó por medianero y abogado al glorioso San José, y lo mucho que le aprovechó», ๆ 7).

19 Juntament amb la seva esposa, Lucrècia, de qui parlarem més endavant, Josep va contribuir a la fundació del convent de Sant Josep de Barcelona el 1586. 
Verònica Zaragoza Gómez. «Cual doctora en cielo graduada... ». La poesia femenina per als certàmens literaris amb motiu de la beatificació i canonització de Teresa de Jesús (València, 1614 i 1621; Barcelona, 1614)

los regozijos que en la Ciudad de Barcelona se mostraron, assí en las primeras nuevas, como en las fiestas principales» (148 f.), conté nombroses poesies i jeroglífics i els sermons predicats; el segon, «Del certamen poético en las fiestas de la madre santa Teresa de Iesús, en la ciudad de Barcelona» (f. 1[bis]89[bis]), no només narra la festa poètica amb les regles dels set certàmens o categories i un completíssim corpus de poesies (Rubió 1984-1986: 125-130; i Rossich 2003: 105) sinó que també descriu alguns aspectes de les festes de Lleida, Tortosa, Perpinyà i Mataró. Finalment, el tercer tractat, recull quatre sermons i un epigrama amb el nom del compilador Dalmau (Ettinghausen 2010: 219-220). Dalmau explica detalladament el gran aparat festiu desplegat a la ciutat comtal per festejar l'efemèride, d'una gran «plasticitat barroca» i «pompa oratòria» en castellà (Rubió 1984-1986: 126); no hi podien faltar les lluminàries, la música urbana, les cavalcades amb jocs i encamisades i torneigs de cavallers, les processons, les ornamentacions urbanes... El protagonisme de la dimensió literària queda palès amb la bona quantitat d'anagrames, sonets, epigrames... que penjaven dels tapissos decoratius i, especialment, amb la celebració del certamen poètic de rigor, que el mateix Dalmau va sufragar. El cartell del certamen especifica els set premis o set categories a què es podien acollir els participants, tant en llengua castellana, llatina com catalana, amb una temàtica prefixada per a tots: els Avisos espirituales atribuïts per la tradició impresa a Teresa de Jesús. ${ }^{20} \mathrm{El}$ tema doncs, eren els seixanta-nou avisos imputats la carmelitana, arran de la seva inclusió en l'edició princeps d'Évora (1583), ${ }^{21}$ i que Dalmau també transcriu. Al llarg dels segles, s'havia considerat que la carmelita va escriure aquests consells espirituals per ajudar les companyes de professió a seguir el camí de perfecció; tanmateix, avui dia, han estat considerat pseudoteresians en ser atribuïts als mestres de novicis jesuïtes, a través dels quals haurien arribat a la santa (Tomás de la Cruz OCD 1961a, 1961b i 1963).La relació de Dalmau reporta els poemes d'uns seixanta-quatre participants que van ser llegits tant al premi com a la devoció (és a dir, sense competir-hi), entre els quals consignem un total de deu autores, ${ }^{22}$ monges o nobles. Si revisem les aportacions poètiques que recull Dalmau, per a la categoria de les octaves, trobem dues peces femenines a la devoció de la santa: les peces pertanyen a Lucrècia Balcells i Puiggarí i sor Elena de Cardona, ambdues de cognoms coneguts. La primera, Lucrècia Balcells (Barcelona, a. 1584-1625), no és una altra que l'esposa de l'organitzador del certamen, el mateix Josep Dalmau, i neboda del canonge de la seu barcelonina, Onofre Balcells. ${ }^{23}$ Procedent d'una família de Valls,

20 «el sujeto o materia sobre que todos han de componer, han de ser los avisos de nuestra santa, tomando uno o dos, o quatro o más, los que cada uno mejor le parecieren. Y alabando el aviso y la santa en quanto se esmeró en las virtudes que en los tales avisos se aconsejan. Hallarse han los avisos entre sus obras, en el fin del libro llamado Camino de perfección...» (Dalmau 1615: [II], f. 2v).

21 En aquesta impressió, els Avisos es reduïen a 68, perquè el primer no va ser numerat.

22 Rubió ja havia remarcat que «no mancaren dames ni religioses a la cita» (1984-1986: 129). Caldria sumar-hi les tres peces laudatòries femenines que Dalmau (1615) va recol lectar als prolegòmens de la relació.

23 L'Arxiu Històric de l'Hospital de la Santa Creu i Sant Pau conserva documentació relativa a Lucrècia: Causes i plets judicials. Vol. I. Inv. 7. Causes judicials, carpeta 11/35. «Lucrècia Dalmau, muller del doctor del Reial Consell Josep Dalmau i successora d'Onofre Balcells, canonge de la seu de Barcelona, contra els administradors de l'Hospital de la Santa Creu, sobre una donació de 500 1l. feta per Balcells a l'Hospital».

SCRIPTA, Revista internacional de literatura i cultura medieval i moderna, núm. 6 / desembre 2015 / pp. 251 - 290 ISSN: 2340-4841 · doi:10.7203/SCRIPTA.6.7832 
Verònica Zaragoza Gómez. «Cual doctora en cielo graduada... ». La poesia femenina per als certàmens literaris amb motiu de la beatificació i canonització de Teresa de Jesús (València, 1614 i 1621; Barcelona, 1614)

fou filla del mercader Pere Balcells, i de Magdalena Puiggarí, i es va casar amb Dalmau ${ }^{24}$ el 1584. Un any més tard, quan aquest, jurista de professió, era conseller (tercer) de Barcelona, arribaren a la ciutat els primers carmelites descalços disposats a fundar l'orde a Catalunya i el matrimoni Dalmau n'esdevingué protector. Gràcies a aquest patronatge, es va poder fundar el convent de Nostra Senyora de Gràcia (o dels Josepets) el 1626 (Martí Bonet, Castro \& Coloma 1987; Narváez 1994: 589-598 i Narváez 2004). Lucrècia Dalmau, però, no veuria la fundació ja que va morir el 21 de febrer de 1625. Tanmateix, una dècada abans, havia pogut retre homenatge poètic a la mestra carmelita a través d'una peça llegida al certamen per la seva beatificació; peça que ens va perpetuar el seu marit en incloure-la a la relació.

Segons llegim a l'octava de Lucrècia, per poder escriure els versos en lloança a la santa, la veu poètica li demana la seva intervenció i el favor diví davant el que considera un seu enginy reduit:

Lo que tengo de hablar en tu alabanza,
Teresa, del aviso fiel traslado,
siendo de tu virtud la semejanza
bien veo que es de Dios afable agrado.
De mi espacioso ingenio en la tardanza
podrá haber falta en no estar bien pensado:
acude con veloz corriente y mide
mis versos, y a tu Dios su favor pide.

A continuació al ludeix a l'arxiconeguda glossa teresiana Vivo sin vivir en mí amb la paràfrasi:

\author{
Si digo que en tu carne no vivías \\ la que eras tú según naturaleza \\ mas Cristo que en tu pecho contenías, \\ 12 \\ atraído a su angélica pureza,
}

Per passar després a parafrasejar l'avís 30é atribuït a la santa: «Haga cada día cincuenta ofrecimientos a Dios de sí y esto haga con gran fervor y desseo de Dios» (copiat per Dalmau 1615: [II], f. 5):

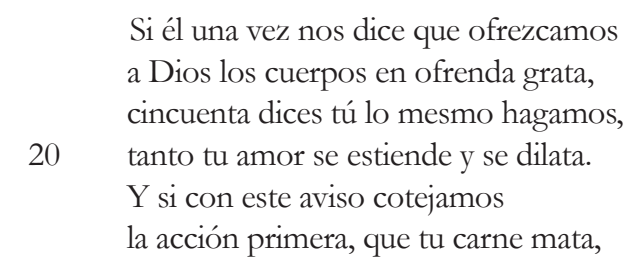

24 A l'Arxiu de la Corona d'Aragó (ACA) es conserva el llibre de memòries de Josep Dalmau (Monacals-Hisenda, vol.
1939), procedent del convent barceloní de carmelites descalços Nostra Senyora de Gràcia, al qual va pertànyer en els
darrers anys de vida. Segons recull la base de dades Manuscrits Catalans de l'Edat Moderna (MCEM [http://
mcem.iec.cat/]), l'ACA conserva a més a més, altres documents interessants per a l'estudi de Josep i que ens
proporcionen informacions sobre Lucrècia.

SCRIPTA, Revista internacional de literatura i cultura medieval i moderna, núm. 6 / desembre 2015 / pp. 251 - 290 ISSN: 2340-4841 · doi:10.7203/SCRIPTA.6.7832 
Verònica Zaragoza Gómez. «Cual doctora en cielo graduada... ». La poesia femenina per als certàmens literaris amb motiu de la beatificació i canonització de Teresa de Jesús (València, 1614 i 1621; Barcelona, 1614)

\author{
si el consejo para otros es cincuenta, \\ 24 las pruebas que en ti vemos son sin cuenta.
}

Uns versos més avall es refereix a altres dos avisos: «25. Siempre te imagina siervo de todos y en todos considera a Cristo Nuestro Señor, y assí le tenrás respeto, reverencia y amon» i «26. Está siempre aparejado al cumplimiento de la obediencia como si te lo mandasse Jesucristo en tu prior o prelado» (Dalmau 1615: [II], f. 4v). I, tot lloant la fervent subjecció de Teresa a Déu, la veu poètica canta la seva santa humilitat:

Su humildad, de virtudes fundamento,
de su profunda sujeción se arguye
convencida de ajeno sentimiento
$44 \quad$ y de que en otros Dios más luz influye;
y así, con santo y soberano intento,
en dos avisos con primor concluye:
que cada cual esclavo se imagine
y a la obediencia su cerviz incline.
[...] (Dalmau 161: [II], f. 38v-39v)

Seguits d'aquests versos, llegim els de sor Elena de Cardona (?): vinculada a la important nissaga catalana dels Cardona, d'ella només hem sabut amb certesa, gràcies al vexamen, que era religiosa:

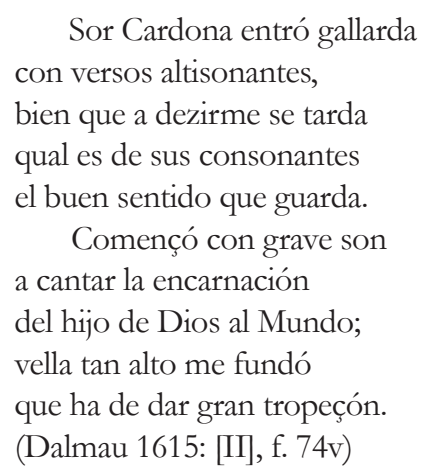

Tot i que se'ns fa difícil precisar-ho, podria tractar-se d'una dominica del convent barceloní dels Àngels, parenta de sor Beatriu (priora de la comunitat) i de Victòria de Josa i de Cardona, amb les quals hauria anat a refundar, el 1596, el convent suprimit de Santa Clara de Vic (Collell 1955).

Sobre les octaves dedicades per aquesta religiosa a Teresa de Jesús és interessant comentar l'aspecte reivindicatiu feminista que el pare Gabriel Beltran Larroya hi va fer notar, per tal com la veu poètica discuteix amb sant Pau per proclamar la carmelita «doctora en cielo graduada». Els versos, per tant, se circumscriuen en un debat teològic en el si de l'església que dura fins als nostres dies i que té a veure amb el paper subordinat femení en el món cristià i la creença de la ineptitud i inconveniència 
Verònica Zaragoza Gómez. «Cual doctora en cielo graduada... ». La poesia femenina per als certàmens literaris amb motiu de la beatificació i canonització de Teresa de Jesús (València, 1614 i 1621; Barcelona, 1614)

de les dones per a parlar dels aspectes divins. Les estrofes, d'una intensa càrrega ideològica, censuren la prohibició de sant $\mathrm{Pau}^{25}$ pel que fa a l'ús de la paraula pública i l'ensenyament per part de les dones,${ }^{26}$ hereves d'Eva («la que por la lengua / al humano linaje puso en mengua», v. 7-8):

Aquel doctor del cielo laureado por doctor de doctores eminentes, que aunque fue de los últimos llamado fue primero en enseñar las gentes, no permite que de doctora el grado a la mujer se dé, ni entre prudentes quiere que hable la que por la lengua al humano linaje puso en mengua.

Versos femenins i profemenins que, sens dubte, degueren ressonar amb força en la cerimònia pública de declamació dels poemes, davant d'«un grande auditorio, de lo más grande de la ciudad presente y con mucha atención» (Dalmau 1615: [II], f. 7v), amb la presència del mateix virrei. Considera el pare Bertran que la poeta religiosa fou la «primera que demanà públicament i "sin rodeos" el doctorat de santa Teresa» (Beltran Larroya 1994: 25); un nomenament com a Doctora de l'Església que, sabem, no arribaria fins al 1970 de la mà de Pau VI. A continuació, la veu poètica centralitza els seus arguments contra les paraules de sant Pau, a través de la vida i obra de Teresa de Jesús, exemple de dona amb empenta que mereixia ser coronada com a doctora per «tan sabia, tan letrada, tan prudente»:

Mas hoy el que de sabios es la fuente una mujer nos muestra prodigiosa, tan sabia, tan letrada, tan prudente, que merece, con laurea muy gloriosa de doctora, ceñir su casta frente: Teresa es ésta, mujer tan misteriosa que con palabras y obras enseñando ser grande en el cielo está mostrando.

25 Cf. «[...] que les dones callin a les assemblees; no els és permès de parlar-hi, sinó que siguin submises, com ho diu fins i tot la Llei. Si es volen instruir sobre algun punt, que ho preguntin a casa als propis marits; perquè no està bé a una dona de parlar en una assemblea» (1Co 14:34-35).

26 Sense entrar en gaires més detalls, cal recordar que mentre que sant Pau també va declarar la igual dignitat en Crist de la dona i de l'home (Ga. 3:28), defensava la subordinació de la dona a l'home en un passatge força obscur que s'ha prestat a moltes interpretacions: «Però vull que sapigueu que de tots els homes, el Crist n'és el cap, com l'home és cap de la dona, i Déu és cap del Crist. Tot home que prega o profetitza amb el cap cobert deshonra el seu cap. En canvi, tota dona que prega o profetitza amb el cap sense cobrir deshonra el seu cap, perquè és exactament igual que si portés els cabells rapats. Per tant, si una dona no es cobreix, que es talli també els cabells; però, si és vergonyós per a una dona de tallar-se els cabells o rapar-se, que es cobreixi. L'home, certament, no s'ha de cobrir el cap, ja que es imatge i reflex de la glòria de Déu; però la dona és reflex de la glòria de l'home. No és pas l'home que prové de la dona, sinó la dona, de l'home. De fet, l'home no fou pas creat per a la dona, sinó la dona per a l'home. Per això, cal que la dona porti un signe de subjecció damunt del cap, per consideració als àngels. D’altra banda, ni la dona sense l'home, ni l'home sense la dona, en el Senyor; perquè, així com la dona prové de l'home, així també l'home existeix gràcies a la dona; i tot prové de Déu» (1Co 11: 3-12). 
Verònica Zaragoza Gómez. «Cual doctora en cielo graduada... ». La poesia femenina per als certàmens literaris amb motiu de la beatificació i canonització de Teresa de Jesús (València, 1614 i 1621; Barcelona, 1614)

\author{
Tuvo sciencia del cielo revelada \\ y, ansí, del cielo su doctrina vino, \\ y, cual doctora en cielo graduada, \\ nos mostró de los cielos el camino. \\ Dionos avisos porque fue avisada \\ con discreción y aviso muy divino, \\ y en el primero la labranza pone \\ que para Dios al hombre bien dispone:
}

Tot seguit, les estrofes següents remeten al primer dels avisos atribuïts a la santa carmelitana, sens dubte, dels més coneguts: «La tierra que no es labrada, aunque más fertil sea, llevará espinas y abrojos: assí es el coraçon del hombre» (Dalmau 1615: [II], f.4):

«La tierra - dice- por fértil que ella sea
si le falta la industria y la destreza
que el tosco labrador en ella emplea,
es forzoso que espinas y maleza
en vez de frutos a sus ojos vea.
Ansí también el hombre que empereza
en su labor esfuerza que no lleve
la flor y fruto que a su dueño debe».
Labrose, pues, Teresa con cuidado,
no quiso, inculta, producir espinas:
de mortificación tomó el arado
y con ayunos, cilicios, diciplinas,
la tierra de su cuerpo cultivado
llevó fruto y flores tan divinas
que a Dios por ramillete se le ofrecen
y a la santa la gloria le merecen.
Desta labor al alma se le sigue
el quedar en lo interior labrada
y luego con cuidado se apercibe
de andar en pensamientos ocupada
de aquel que por esposa la recibe
y, como a tal, le entrega la posada,
mirando con los ojos de su mente
en todo lo que hace a Dios presente.
[...] (Dalmau 161: [II], f. 40-41)

Més enllà d'aquestes dues peces, per al tercer certamen, el cartell demanava cinc estrofes rematades amb «aquella de Garcilaso que comiença: 'Claros y frescos ríos, etc' ${ }^{27}$ i, dels sis autors que recull

27 «Claros y frescos ríos \& c.» (Dalmau 1615: [II], f. 3), cançó que, en realitat, pertany a Joan Boscà, inspirada en el vers 
Verònica Zaragoza Gómez. «Cual doctora en cielo graduada... ». La poesia femenina per als certàmens literaris amb motiu de la beatificació i canonització de Teresa de Jesús (València, 1614 i 1621; Barcelona, 1614)

Dalmau, tan sols un té nom de dona: el de la desconeguda Teresa del Calvari. ${ }^{28}$ D'ella tan sols sabem el que reporta la rúbrica de la peça: que era caputxina a Saragossa. Ara bé, tal com ha fet notar M.M. Gras, ${ }^{29}$ als estudis de M. Carmen Marín (2013 i [en premsa]) dedicats a les participants femenines dels certàmens aragonesos, no hi apareix cap religiosa amb aquest nom. Això, juntament amb el fet que les caputxines, generalment, no solien canviar el seu nom seglar per un de religiós, ha conduit a Gras a plantejar-se la identitat real que hi hauria rere aquest 'pseudònim'.

Així, en les hipòtesis de què parteix l'estudiosa, recorda que el primer convent caputxí aragonès fou creat a finals de maig d'aquell mateix 1614 per una comunitat de religioses de Barcelona, encapçalades per Maria Àngela Astorch: segons Gras, podria haver estat la mateixa Astorch qui, amb identitat encoberta o falsa, enviés la cançó per al certamen poètic barceloní mentre residia al convent de Saragossa. Alguns arguments que addueix per sostenir-ho són les vinculacions de la caputxina, d'una gran cultura intel lectual i important obra escrita, amb l'orde i espiritualitat carmelitana descalça; uns lligams que haurien començat a l'àmbit familiar: Gras recorda que la mare de les Astorch havia tingut un director espiritual d'aquest orde, i que l'oncle, el llibreter Rafael Nogués va assumir l'edició de les obres de Teresa de Jesús, a Barcelona, com ja hem tingut oportunitat de revisar; relacions d'Astorch amb el Carmel descalç que es refermarien durant la seva vida religiosa, especialment a través dels confessors i la influència de les lectures d'espiritualitat carmelitana. Al capdavall, M.M. Gras considera que l'única religiosa possible a la qual podem atribuir aquesta cançó és, doncs, la dita Maria Àngela Astorch «tant per tradició familiar com per la lectura de l'obra teresiana, així com per celebrar-se en la seva ciutat natal». Per aquesta participació, la religiosa és esmentada al vexamen «amb alguns trets distintius de la religiositat de la caputxina: els instruments de disciplina física i la seva devoció al rosari («nácar y rosa») i al breviari»-no debades és coneguda com la mistica del breviari. ${ }^{30}$ Les raons esgrimides per Gras per considerar Astorch l'autora encoberta d'aquests versos semblen encertades, de manera que podríem considerar que fou aquesta la sor Teresa guardonada amb el segon premi en aquesta categoria, tal com llegim a la sentència. ${ }^{31}$

Si ens fixem en la peça guardonada, l'autora compara els Avisos amb un poncell de flors («flores, rosas y narcisos finos», v. 36), com la mateixa Teresa de Jesús que hi és presentada com «otra divina flora» (v. 37):

petrarquià «Chiare, fresche e dolci acque».

28 Recollida per Serrano y Sanz (1915: I, 109-111); i Abad (1994: 547-548), sense cap dada adjunta, malgrat que transcriuen el poema (Abad només fragmentàriament, copiat de l'anterior).

29 En l'entrada publicada a Castell Interior: «La caputxina que cantà la beata Teresa: Teresa del Calvario, pseudònim poètic de Maria Àngela Astorc (1592-1665)?» [consulta: 10/10/2015].

30 «Sor Teresa del Calvario, / religiosa capuchina / con cilicio y breviario, / con rosario y diciplina, / quiso baylar un canario. / Y como esta religiosa, / siempre entre nácar y rosa, / procura vencer su esphera, / ni en el baile la primera fue / ni la más venturosa» (Dalmau 1615: [I], f. 75).

31 «A sor Teresa le den / de Christo la imagen sacra, / que en la cruz de évano cuelga / para remediar sus ansias» (Dalmau 1615: [II], f. 78v). 
Verònica Zaragoza Gómez. «Cual doctora en cielo graduada... ». La poesia femenina per als certàmens literaris amb motiu de la beatificació i canonització de Teresa de Jesús (València, 1614 i 1621; Barcelona, 1614)

28

32

36

40

44

48

52
Suele el aurora blanca

cuando sale mil flores

dar de albricias con mano franca al día,

y dar con mano franca

al cielo mil colores

bañando tierra y cielo de alegría;

pues Teresa venía

al mundo cual aurora

sus avisos divinos

son flores, rosas y narcisos finos,

porque es Teresa otra divina flora que suave olor espira

y cielo y tierra con su luz admira.

Que un eterno deseo

de su Dios tenga el alma,

ardiendo en él Teresa nos avisa, pues tan divino empleo

$\mathrm{y}$ tan digno de palma

Euterpe has de cantar por ley precisa.

Éste el alma matiza,

esmalta y hermosea;

éste a Teresa abrasa

que su corazón vuelve pura brasa.

Ella hace que su luz clara se vea:

que se transforme hermosa

en Dios como divina mariposa. ${ }^{32}$

[...] (Dalmau 1615: [II], 43v-44)

Per a la quarta categoria o certamen, d'entre tots els tercets copiats per la relació de Dalmau, notem la presència d'una única dona. Es tracta de Graïda de Blanes i de Tamarit (Barcelona c. 1570- d. 1641), ${ }^{33}$ filla de Ramon de Blanes i de Centelles, senyor de Villalba Sasserra i comte de Centelles, i de Marina de Tamarit i de Torrelles. ${ }^{34}$ Era coneguda com a Graïda de Pinós i de Blanes, arran del seu casament, el 1593, amb Pere de Pinós Sancliment i de Gualbes. ${ }^{35}$ Graïda va ser, juntament amb

32 El motiu de la papallona com a metàfora de l'ànima que se sent atreta per la flama és present en l'art europeu des de l'Antiguitat, amb un gran simbolisme espiritual. Respecte a la presència d'aquest motiu antic en la lírica hispànica barroca, llegiu Trueblood (1977).

33 Recollida per Serrano y Sanz (1915: I, 112-114), sense cap dada més enllà de l'obra.

34 Veg. l'entrada de M. Gras que li dedica a l'Exposició virtual: V Centenari del naixement de Teresa de Jesús (2015). Exposició "Escribo con libertad", detallant-ne aquesta obra [consulta: 4/10/2015].

35 Es conserva un procés judicial amb data de 1630, de Peronella Amat contra Graïda de Pinós sobre l'herència de Joan Cabaner, àlies Cabalera: AHSCP, Causes i plets judicials. Vol. I. Inv. 7. Causes judicials, carpeta 1/74.; veg. un altre procés conservat sobre Graïda a ACA, REAL AUDIENCIA, Plets civils, 15204 i ACA, REAL AUDIENCIA, Plets civils, 29920. 
Verònica Zaragoza Gómez. «Cual doctora en cielo graduada... ». La poesia femenina per als certàmens literaris amb motiu de la beatificació i canonització de Teresa de Jesús (València, 1614 i 1621; Barcelona, 1614)

Josep Dalmau, una de les màximes protectores del convent dels carmelites descalços de Sant Josep de Barcelona (escenari de celebració del certamen), fundat el 1586 (fet que explicaria el seu desig de cantar a la flamant beata):

\begin{abstract}
Cosa muy notable fue la devoción que toda Barcelona tomó en nuestro convento después que enpeçaron a ser conocidos sus religiosos. Como a porfía se esmeravan en frequentarla, asistirla y socorrerla, y como hallavan allí el exemplo, la edificación, la enseñança y todo su consuelo y bien espiritual, le desseavan favorecer sumamente. Quien a los principio se señaló mucho fue doña Graida de Pinós y de Blanes, muger de don Pedro de Pinós Gualbes y Sanclemente, nobilíssima casa deste Principado. Mientras vivió fueron continuas su limosnas (Gras 2013: 256). ${ }^{36}$
\end{abstract}

Seguint amb el certamen, el cartell demanava per a aquesta categoria «veynte tercetos» $i$, a aquestes condicions, s'hi va cenyir Graïda. Cal destacar-ne els versos:

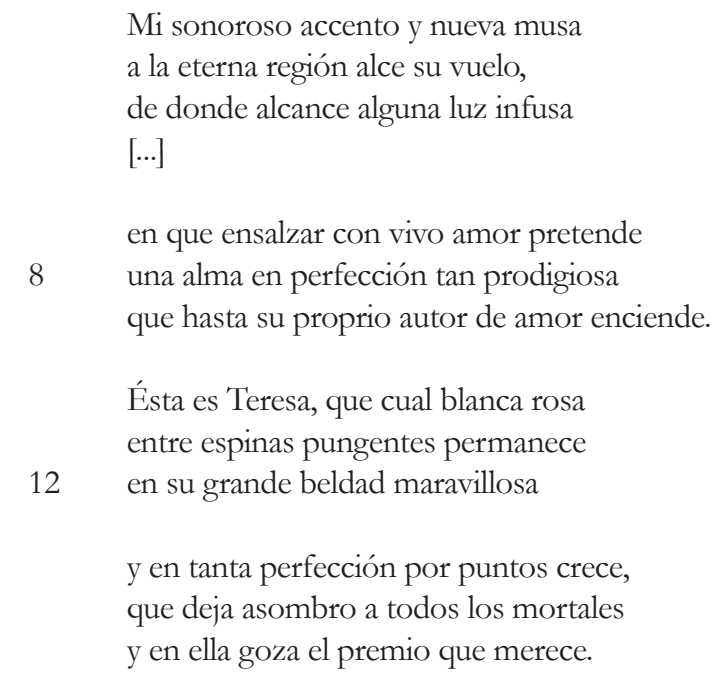

A partir del vers 24 llegim una remissió a l'Aviso 23: «Cada obra que hizieres dirigirla a Dios, ofreciéndosela y pedirle que sea para su honra» (Dalmau 1615: [II] 429):
16 Ésta es aquella que, en Avisos tales como a sus hijos puros comunica, los vuelve de terrenos celestiales.

\footnotetext{
36 Tot citant les paraules de Joan de sant Josep, Annales (Ms. 991, Biblioteca Universitària de Barcelona). A més a més, recull Gras en la dita entrada extreta de l'exposició virtual que Graïda freqüentava el convent de les carmelites descalces de Barcelona: «[...] grande amiga de su madre, se la llevava las más mañanas a missa y, teniendo deudas y conozidas en essa comunidad les hazía algunas visitas».
} 
Verònica Zaragoza Gómez. «Cual doctora en cielo graduada... ». La poesia femenina per als certàmens literaris amb motiu de la beatificació i canonització de Teresa de Jesús (València, 1614 i 1621; Barcelona, 1614)

\author{
Ésta es aquella que la mano aplica \\ 20 al cumplimiento fiel de lo que exhorta, \\ quedando en él con gran ventaja rica. \\ Ésta es la que, mirando cuanto importa \\ cualquier obra a su Dios ser dirigida, \\ 24 enseña al alma en esto no ser corta \\ haciendo oferta de ella engrandecida, \\ para honra y gloria de su nombre santo, \\ en que quede con premio enriquecida. \\ [...] (Dalmau 1615, f. 50v-51; editat també per Serrano y Sanz 1915: I, 112-114)
}

Graïda apareix citada al vexamen com a poeta celebrada que no va decebre les expectatives del públic. ${ }^{37} \mathrm{I}$ la sentència, on consta com a segona guanyadora de la categoria (Rossich 2003: 105) ho corrobora amb l'epítet de dona «sabia»; paraules que demostren que aquesta dona tenia un cert prestigi i reconeixement social, i que era coneguda en el context d'aquelles festes. ${ }^{38}$ Aquesta autora hi va tornar a concursar, amb dues peces més, a les categories següents, com veurem més avall.

Sens dubte, el cinquè certamen va ser el que més dones creadores va reunir, ja que dels dotze participants que hi van concórrer, quatre foren dones, amb versos que havien de glossar una quarteta donada pel cartell. Una d'aquestes fou la mateixa Graïda, amb una dècima adreçada a la santa que s'inicia exalçant-ne l'agudesa:

$\begin{aligned} & \text { Tiene la vista Teresa } \\ & \text { de tal perspicacidad } \\ & \text { que hasta el Jordán atraviesa } \\ 8 \quad & \text { do adora la Trinidad } \\ & \text { que cielo y tierra confiesa; } \\ & \text { cuyos ojos aunque están } \\ & \text { tan lejos discernirán } \\ & \text { cual ven de los dos primero: } \\ & \text { si en la orilla ven Cordero, } \\ & \text { si paloma, en el Jordán. } \\ & {[. . .] \text { (Dalmau 1615: [I], 57v-58) } }\end{aligned}$

També hi consten els versos de la noble Anna Magdalena de Tamarit i Guardiola. D’aquesta sabem que posteriorment es va casar amb Lluís de Corbera i de Castellet, després de signar capítols matrimonials a Barcelona el 1618 (Cadenas 1987: 96). Els versos que va llegir al certamen aquesta dama, aleshores

37 «Con tercetos, la primera / doña Grayda Pinós, / dançó qual della se espera, / que en ella se esmera Dios / y el cielo en ella se esmera. / Con tal donayre y desdén / nos dança, que aunque le den / una corona de perlas, / ella para merecerlas / bayla sobrado de bien» (Dalmau 1615, [I], f. 75v).

38 «A doña Grayda Pinós / quiero tratar como sabia / y assí el breviario y diurno / por premio se le señala» (Dalmau 1615:[II], f. 78v). 
Verònica Zaragoza Gómez. «Cual doctora en cielo graduada... ». La poesia femenina per als certàmens literaris amb motiu de la beatificació i canonització de Teresa de Jesús (València, 1614 i 1621; Barcelona, 1614)

donzella, li van merèixer lloances hiperbòliques al vexamen, on apareix citada com a «alta y divina Thalía»; ${ }^{39}$ fins al punt que en va resultar guanyadora del primer premi de la seva modalitat (Rossich 2003: 105). ${ }^{40}$ En la composició aportada, exalça la ploma de Teresa de Jesús, com a intermediària del llenguatge diví («voz», «pluma»), amb la idea que tot allò que escriu li ha estat revelat per Déu (v. 35-44):

Es voz que de su Señor
misericordias canta
Teresa y su lengua santa;
es pluma del summo amor
del gran Dios que la levanta;
con velocidad escribe
lo que dictando le van:
el Hijo y Padre le dan
y el espíritu apercibe
y enseña como a san Juan.
[...](Dalmau 1615: [I], f. 56)

A aquesta mateixa modalitat de les glosses també van concórrer dues religioses, per bé que tan sols d'una d'elles podem provar documentalment que ho fos: es tractaria de la dominica sor Teresa de Preixana (i Calvo?) (Barcelona?, c. 1602-1677), ${ }^{41}$ de qui sabem que el 1613 (només un any abans de la celebració de les festes a Teresa de Jesús) va vestir l'hàbit al convent dels Àngels i Peu de la Creu de Barcelona, on professaria quatre anys més tard, el 1617. Va arribar a ser-ne sotspriora de la comunitat, amb Anna M. Aymeric (1662-1665) i Àngela Masmitjà (1665-1668). ${ }^{42}$ Segons les dates de què disposem, doncs, quan va aparèixer el poema a nom de sor Teresa, aquesta tenia a l'entorn de dotze anys i ni tan sols encara era professa de la comunitat. Segurament, el fet de pertànyer a una família noble, va motivar l'aparició de la seva peça en una trobada social i literària tan distingida: devia d'estar emparentada amb Pau Benet de Preixana, doctor en dret, assessor del General de Catalunya, pare de Domènec de Preixana i de Lafita, ciutadà honrat, doctor de la Reial Audiència, catedràtic de lleis i cànons amb oposició a l'Estudi de Barcelona, pare, a la seva vegada, de Pau de Preixana i Calvo, ennoblit el 1650. L'aparició del nom de sor Teresa a la rúbrica d'una peça dedicada a Teresa de Jesús, doncs, ens fa plantejar-nos l'interès de fer-la-hi constar com a autora, amb només dotze anys, amb uns versos encarregats a un altre poeta. En aquest cas, podríem entreveure l'afany

39 «Doñ’Ana de Guardiola, / alta y divina Thalía, / qual phénix única y sola / entró al declinar del día / y al entrar, Apolo viola. / Viola Apolo y como vio / tal milagro, se paró / solo por vella dançar. / No vio el Sol más singular / mujer desde que nació» (Dalmau 1615: [II], f. 77v).

40 Tal com s'explicita a la sentència: «Doñ’Ana de Guardiola, / desta vez triumfa ufana / con rico relox de muestra / y su glosa aun no se paga» (Dalmau 1615: [II], f. 78v).

41 Dades procedents de Mercè Gras, a qui agraïm la informació.

42 El 1672 pledejava contra Eulàlia, vídua de Pau Amat, reclamant els llegats testamentaris que feren a dita monja Teresa (Amat) de Cardona i Elena (de Cardona) Calvo.

SCRIPTA, Revista internacional de literatura i cultura medieval i moderna, núm. 6 / desembre 2015 / pp. 251 - 290 ISSN: 2340-4841 · doi:10.7203/SCRIPTA.6.7832 
Verònica Zaragoza Gómez. «Cual doctora en cielo graduada... ». La poesia femenina per als certàmens literaris amb motiu de la beatificació i canonització de Teresa de Jesús (València, 1614 i 1621; Barcelona, 1614)

d'alguns progenitors (o dels convents de religioses, amb el desig d'augmentar el seu radi d'influència $\mathrm{i}$ de visibilitat social) per presentar les nenes en aquestes reunions de caire social ${ }^{43}$ i de mostrar-les com a prodigis, en una tradició que tindria els seus orígens en l'humanisme i que es perllongaria fins ben entrats el segle XVIII. ${ }^{44}$

Siga com siga, sobre la peça atribuïda a aquesta religiosa, presentada a la devoció, destaquem la bellesa dels versos:

Porque Teresa sagrada
fue cara paloma y pura,
como a consorte procura
para que sea estimada
manifestar su pintura.
Que, aunque la cubre, verán
los que sus trazas sabrán
que su transparente sombra
la apunta, señala y nombra
y enseña como a san Juan.
[...](Dalmau $1615:[11]$, f. $59 \mathrm{v}-60)$

Més enllà d'aquesta, Francesca Toledo també va aportar una composició a la festa poètica; en documentació sobre violaris consultats a la $\mathrm{BC}^{45} \mathrm{amb}$ data de 1628 , hi consignem una dona amb aquest nom com a monja de Montsió. Però no podem verificar la dada pel fet que no apareix cap menció del seu estatus religiós a la rúbrica de la peça. De fet, tampoc no consta el seu nom al vexamen sinó que l'hem d'incloure al grup de poetes participants a la categoria de les glosses. ${ }^{46}$

Els versos de Francesca destaquen la pobresa de Teresa de Jesús com a virtut que li va permetre arribar a Déu:

43 Dins l'esfera dels certàmens catalans, és conegut el cas de Magdalena Agullana (Girona 1609-?, 1669), Francesca Agullana (Girona 1612-1628) i Oròsia Agullana (Girona, 1615-?, d. 1641), a nom de les quals van aparèixer signats tres poemes per al certamen celebrat el 1622 a Girona, a la canonització dels sants Ignasi de Loiola i de Francesc Xavier, i a la beatificació de Lluís Gonçaga, organitzat pel matrimoni Martí Sanz de Latrás d’Agullana i Elionor Agullana de Sarriera, progenitors de les tres nenes.

44 Per al segle xviII, comptem amb la pràctica documentada d'exhibició de la vasta cultura de noies de la noblesa, com a mitjà de distinció, a través del cas de Cayetana de la Cerda y Cernecio, filla dels comtes de Parcent, que a quinze anys va actuar amb el seu germà en una festa celebrada a sa casa valenciana el 1763 (Bolufer 2009: 74-76) i de la mallorquina il lustrada sor Pasquala Caro (Palma, 1768-1827) que a dotze anys es va sotmetre a un examen públic. Amb aquests exàmens, que es van imprimir sobretot al segle xvIII, es pretenia «exhibir en sociedad los conocimientos intelectuales y las refinadas maneras de sus hijos de ambos sexos, buscando así un efecto de distinción a través de la cultura» (Bolufer 2009: 74-82).

45 BC AH. Capsa 22 (bis), núm., 10571, any 1628, 4 f.

46 «Un pie de chibao dançaron/ doze poetas en paz,/ todos juntos començaron/ y baylaron un compás,/ aunque sin compaz baylaron./ Yo nunca tal cosa vi,/ yvan dando aquí y allí/ pernadas y cabriolas, / y assí dexallos assoladas / por mejor tuve y me fuy» (Dalmau 1615: [II], f. 77v). 
Verònica Zaragoza Gómez. «Cual doctora en cielo graduada... ». La poesia femenina per als certàmens literaris amb motiu de la beatificació i canonització de Teresa de Jesús (València, 1614 i 1621; Barcelona, 1614)

16

20
Cuya divina pobreza

fue tan rica para vos

que os hizo manjar de Dios

y fue el pan de vuestra mesa.

Por pobre fuisteis, Teresa,

rica en la suerte que os cubre

que es rico el pobre que encubre

el mundo, pues Dios le llama;

que solo el que es pobre y ama

al hijo de Dios descubre.

Recordó vuestra memoria viendo que es la vida incierta

que hay una alma y muerte cierta, triste infierno o dulce gloria;

y así tuvisteis vitoria

porque al que Dios se descubre

y humilde al mundo se encubre,

cubre Dios con su amor santo

y así, con su eterno manto,

a nuestra Teresa cubre.

[...](Dalmau 1615: [II], f. 57)

Graïda de Blanes i Centelles (signant amb el nom de Graïda Pinós) va tornar a resplendir amb una peça aportada a una nova categoria, la sisena, dedicada a les dècimes. Pel que fa a aquesta categoria és interessant remarcar-ne el protagonisme femení, ja que dels set participants que Dalmau recull, més de la meitat en són dones. Seguint amb Graïda, aquesta nova peça, li va valer una nova aparició al vexamen. El text remarca la seva saviesa sense haver rebut estudis superiors reglats («sin haber estudiado»), com era l'habitual per a les dones de l'època:

\author{
Esta española cerró, \\ doña Grayda de Pinós: \\ una y otra vez bayló \\ $\mathrm{y}$ al fin en los bayles dos, \\ bien quien era nos nos [sic] mostró. \\ Como en todo es peregrina \\ tiene la vena divina \\ y sin haber estudiado \\ se le puede dar el grado \\ en la escuela salmantina. \\ (Dalmau 1615: [I], f. 76v-77)
}

Dels versos dedicats per Graïda a Teresa de Jesús, podem destacar-ne l'exaltació de la humilitat de la carmelita, com a virtut que li va ser recompensada per Déu: 
Verònica Zaragoza Gómez. «Cual doctora en cielo graduada... ». La poesia femenina per als certàmens literaris amb motiu de la beatificació i canonització de Teresa de Jesús (València, 1614 i 1621; Barcelona, 1614)

\author{
Humilde fuisteis, Teresa, \\ porque Dios, que al alma cela, \\ solo al humilde revela \\ 64 \\ las minas de su riqueza. \\ No hay bien de mayor grandeza \\ para la inmensa deidad \\ mayor que virginidad, \\ 68 \\ que la Virgen que parió \\ si por virgen agradó \\ concibió por la humildad. \\ [...](Dalmau 1615: [I], f. 60v-61v)
}

En aquesta mateixa categoria trobem tres peces més signades per dones: els d'Anna Meca, de Joana o Teresa Enríquez i de Joana Ferran. La primera no va competir al premi sinó que hi va aportar unes dècimes castellanes a la devoció; es tractaria d'Anna Ivorra i Raset (a. 1601-d. 1654), ${ }^{47}$ filla i hereva de Guillem d'Ivorra, governador dels Comtats del Rosselló i la Cerdanya (1599-1615). A la rúbrica apareix com a Anna Meca perquè va estar casada amb Frederic de Meca-Clasquerí i de Caçador (...1654), procedent de la important nissaga catalana dels Meca (Martínez Rodríguez 1993), baró de Castellar i senyor de Ribatallada, que apareix esmentat també a la relació de Dalmau, com a partícip de la festa (1615: [], f. 4v i 26). Aquesta dama estava ben posicionada a l'època ja que, ens han arribat les lloances d'Esteve de Corbera, el 1629, a la hagiografia dedicada a Maria de Cervelló, en els termes següents:

\begin{abstract}
Sin don Dalmao de Ivorra en quien se conserva por varonía la nobleza i el apellido del linage de Ivorra, vive agora doña Ana, ija i eredera de don Guillem Ivorra, que murió governador de los condados i provincias del Rossellón i Cerdaña, i mujer de don Fadrique Meca i de Clasquerí. Parece que faltara a mi obligación si entre las grandezas de vna santa virgen [Maria de Cervelló] dexara de azer memoria de una señora casada, a quien el respeto común venera como espejo de virtud. Su recogimiento, su devoción, sus exercicios i obras son tan exemplares que admiran i consuelan i se llevan tras sí la estimación de todos (Corbera 1629: f. 59v).
\end{abstract}

De fet un anys abans, Jaume Rebullosa la feia aparèixer en la seva narració de les festes celebrades a Barcelona el 1601 en honor a la canonització de sant Ramon de Penyafort; segons la dita referència, Anna es va encarregar d'ornamentar el tabernacle de sant Vicent Ferrer: «La mucha voluntad con que Doñana de Meca y de Yvorra se ofresció para componer el tabernáculo de san Vincente Ferrer dió bien claras muestras de quán particular devota le es y de lo mucho que podíamos esperar haría en su adorno...» (Rebullosa 1601: f. 183); informació que ens dibuixa el perfil i l'empenta d'aquesta dona d'una família distingida de la Barcelona del moment, que va participar en l'entramat festiu i cultural

47 Així ho llegim en processos i al legacions impreses: Iuris responsum pro Bertrando Desvall contra nobilem Annam Mecha, et de Yvorra, in causa carlaniae de la Guardi ad relationem magnifici Francisci Gamis R. Aud. Doct., (Barcelona: Llorenç Déu, 1620) i Iuris responsum pro Ioachimo Valls et de Santcliment et Agnete eius vxore contra nobiles Federicum Meca, \& Annam consortem suam (Barcelona: Stephanum Liberos, 1625). 
Verònica Zaragoza Gómez. «Cual doctora en cielo graduada... ». La poesia femenina per als certàmens literaris amb motiu de la beatificació i canonització de Teresa de Jesús (València, 1614 i 1621; Barcelona, 1614)

de l'època, i va protagonitzar variades iniciatives culturals. Una prova de la seva implicació en els espais de sociabilitat literària de l'època, avui desdibuixats per manca de documentació, la revela també el fet que va aportar una poesia laudatòria per als prolegòmens de l'imprès del militar i poeta barceloní Vicenç M. de Moradell: Historia de S. Ramon de Peñafort (Moradell 1603: f. 15v).

Dels versos que Anna Ivorra aporta a concurs, destaca la lloança a l'obra doctrinal de la santa, amb paràfrasis d'un dels seus avisos:

\begin{tabular}{|c|c|}
\hline & Alabo, Tere \\
\hline & tu virtud y tu doctrina, \\
\hline & pues, por rara y peregrina, \\
\hline 4 & $\begin{array}{l}\text { los más perfectos espanta; } \\
\text { la falsa razón quebranta }\end{array}$ \\
\hline & de los hombres engañados \\
\hline & que, ofendidos y agraviados, \\
\hline 8 & luego a vengar se aperciben \\
\hline & $\begin{array}{l}\text { las injurias que reciben, } \\
\text { de tu consejo olvidados. }\end{array}$ \\
\hline & {$[\ldots]$} \\
\hline & «A quien hubiere reñido ${ }^{48}$ \\
\hline 36 & -dice Teresa, prudente-, \\
\hline & no muestres triste la frente \\
\hline & ni sientas pena en el alma; \\
\hline & resiste cual fuerte palma \\
\hline 40 & y acude a Dios diligente». \\
\hline & Como en lo demás en esto \\
\hline & fue trompeta artificiosa, \\
\hline & que a su consonancia hermosa \\
\hline 44 & la mano ayuda tan presto. \\
\hline & Como de la boca el gesto \\
\hline & manda y humilde obedece, \\
\hline & y los Avisos que ofrece \\
\hline 48 & de tal arte los ordena \\
\hline & que, si habla, está de obras llena \\
\hline & $\begin{array}{l}\text { y un centímano parece. } \\
{[\ldots] \text { (Dalmau 1615: [I], f. 64v-65) }}\end{array}$ \\
\hline
\end{tabular}

A diferència d'aquesta, la informació biogràfica de què disposem de les altres dues participants que Dalmau recull en aquesta categoria és molt minsa. Seguint amb la relació, hi llegim les dècimes

48 Recorda l'Avís 45 «Quando algo te reprehendieren, recíbelo con humildad interior y exterior, y ruega a Dios por quien te reprehendió» » (Dalmau 1615: [II], f. 5v).

SCRIPTA, Revista internacional de literatura i cultura medieval i moderna, núm. 6 / desembre 2015 / pp. 251 - 290 
Verònica Zaragoza Gómez. «Cual doctora en cielo graduada... ». La poesia femenina per als certàmens literaris amb motiu de la beatificació i canonització de Teresa de Jesús (València, 1614 i 1621; Barcelona, 1614)

castellanes de Joana o Teresa Enríquez ${ }^{49}$ (?), que celebren la glòria de la santa (amb la seva beatificació), per davant de la de «mil ilustres varones»:

Responden, divina santa,

con debida proporción

al grado de perfección

que en tu sujeto fue tanta,

que la Iglesia te adelanta

16

hoy con divinos pregones

a mil ilustres varones

cuya preclara memoria

no ensalza tanto su gloria

20

como a ti tus altos dones.

Dejándote por dechado

de cuanto vida recibe

el que en ti por gracia vive

24 en tan soberano grado,

que, viéndose enamorado

de los actos que produces,

convierte en divinas luces

28 para poderse mejor

ver del justo y pecador

que a tu estimación reduces.

$[\ldots]$

Abono de esta verdad

es el divino blasón

de tu beatificación

44

en que tu pura beldad

cobra tan gran majestad

que la que el mundo en sí encierra

la adora; puestas por tierra,

48 con humildad, sus rodillas

y las altas maravillas

que tu santidad encierra.

No mostrándola menor

52

en los avisos divinos

de tu gran perfección dignos,

fundados en vivo amor; como exhortar al fervor

56 de cincuenta ofrecimientos ${ }^{50}$

a aquel Dios que tiene atentos

en sí los coros del cielo

49 Rossich (2003: 105) dubta entre el nom de Joana i Teresa, perquè, malgrat que el poema va signat amb el nom de Joana Enríquez, la confusió la genera el vexamen; una altra possibilitat és que tinga el nom compost de Joana Teresa.

50 ‘Com l'avís de Teresa que exhorta a fer cinquanta oferiments a Déu’: «30. Haga cada día cincuenta ofrecimientos a Dios de sí y esto haga con gran fervor y desseo de Dios» (Dalmau 1615: [I], f.5).

SCRIPTA, Revista internacional de literatura i cultura medieval i moderna, núm. 6 / desembre 2015 / pp. 251 - 290 
Verònica Zaragoza Gómez. «Cual doctora en cielo graduada... ». La poesia femenina per als certàmens literaris amb motiu de la beatificació i canonització de Teresa de Jesús (València, 1614 i 1621; Barcelona, 1614)

60

porque al alma en este suelo

crezcan los merecimientos.

[...](Dalmau 1615: [II], f. 63-64v)

Malgrat que Enríquez va resultar la guanyadora del tercer premi en la seva categoria (Rossich (2003: $105)^{51}$ al vexamen, aquests versos hi són criticats d'acord amb el to satíric del gènere:

\author{
De Enríquez, doña Teresa, \\ como interessada al fin \\ con una española empieça, \\ mas tropeçó en un chapín ${ }^{52}$ \\ y en sus décimas tropieça. \\ Por premio le quedará \\ el «Dios te ayude» de acá \\ con que al caer la ayudamos, \\ y si premio no le damos, \\ Teresa se lo dará. \\ Fueron sus décimas buenas \\ y pudieran ser mejores \\ pues no se sacan apenas \\ los avisos y loores \\ de sus confusas dezenas. \\ (Dalmau 1615: [II], f. 76)
}

Finalment, completa la nòmina de les autores en aquesta categoria la religiosa d'origen noble sor Joana Ferran (?) de la qual hem conservat els versos castellans que reporta Dalmau però no en tenim cap identitat. Només gràcies al fet que apareix esmentada al vexamen, sabem que era una religiosa jove:

\footnotetext{
De veynte años, religiosa, mujer noble, tierna y flaca, dis que es cosa peligrosa que no tomasse triaca de la diestra poderosa.

A Dios haze boticario y assí pierde el relicario porque quien a Dios afrenta no es razón que el favor sienta ni le enriquezca su erar[i]o.

En esta bayle el donayre de doña Ioana Ferran se mostró bien que al desgayre
}

51 «A doña Teresa Enríquez, / con herramienta doblada, / dos estuches le darán, /que sus décimas lo ganan» (Dalmau 1615: [II], f. 78v).

52 chapin: tipus de sandàlia que portaven les dones de tela fina i sola de suro. En català 'tapí.

SCRIPTA, Revista internacional de literatura i cultura medieval i moderna, núm. 6 / desembre 2015 / pp. 251 - 290 
Verònica Zaragoza Gómez. «Cual doctora en cielo graduada... ». La poesia femenina per als certàmens literaris amb motiu de la beatificació i canonització de Teresa de Jesús (València, 1614 i 1621; Barcelona, 1614)

\author{
y si el premio no le dan \\ no tire piedras al ayre. \\ Porque el ángel de su guarda \\ era de vena muy tarda \\ y muy mal exercitado; \\ más pues es tan confiado, \\ él le dé el premio que aguarda. \\ (Dalmau 1615: [II], f. 76v)
}

A la seva obra, després de lloar les mercès divines rebudes per la carmelitana d'Àvila, remarca la qualitat de la seva obra escrita i la seva saviesa, contemplades com a gratia gratis data:

Otras mil gracias la dio:
que en todo fuese esmerada
y la hizo su letrada
donde su saber midió.
Con muchos sabios se vio
que a su gracia se humillaron
y entre sus letras hallaron
camino de la virtud
con que la entera salud
de entre sus libros sacaron.
Sus Avisos nos avisan
si de Dios queremos palma
que no dejemos el alma
ir por donde todos pisan;
porque muchos se divisan
con el mundo y sus antojos,
es bien que abramos los ojos
y la fiesta celebremos
de Teresa y sus estremos
dándole a Dios los despojos.
[...] (Dalmau 1615: [11], f. 65)

Per acabar amb aquest certamen, cal dir que d'aquests dotze poemes femenins impresos que ha transmès la relació de Dalmau, ens han n'arribat, a més, dos testimonis manuscrits, copiats a un volum de procedència carmelitana: es tracta de les peces de Graïda Grimau i de Joana o Teresa Enríquez, agrupats amb d'altres composicions que versen fonamentalment sobre Teresa de Jesús. Es troben recopilats al volum inèdit de la Biblioteca de la Universitat de Barcelona: Opúsculos espirituales, una miscel lània amb textos espirituals, literaris i poètics. Possiblement pertanyia al convent de carmelites descalços de Sant Josep, Barcelona, fet que explicaria que volguessen copiar una composició de la seva 'protectora', amb el nom complet i els dos cognoms, tal com 
Verònica Zaragoza Gómez. «Cual doctora en cielo graduada... ». La poesia femenina per als certàmens literaris amb motiu de la beatificació i canonització de Teresa de Jesús (València, 1614 i 1621; Barcelona, 1614)

es llegeix a la rúbrica: «Terçetos a nuestra santa madre de dona Agreïda de Pinós y Blanas» ${ }^{53}$ -nom complet que, en canvi, no reporta l'original, on només apareix com a Graïda de Pinós. A diferència d'aquesta, l'altra peça d'autoria femenina que fou copiada al manuscrit, apareix de manera fragmentària i anònima, tot i que sabem que pertany a Joana o Teresa Enríquez gràcies al testimoni imprès. ${ }^{54}$

\section{III. Saragossa}

En la nòmina de participants que refereix Dalmau advertim que són molts els cognoms catalans, però també hi ha castellans i aragonesos, mentre que d'altres són personatges difícils de situar geogràficament; en aquest sentit, cal advertir la mobilitat de participants en aquestes certàmens emmarcats en les festes celebrades a tota l'àrea hispànica. De fet, per al certamen barceloní, Dalmau havia convocat a la participació «a las Docticanas y loquazes musas de nuestra Europa» (1614: 2) i, concretament, als ingenis espanyols:

para lo qual a los últimos del mes de agosto se publicó en esta ciudad de Barcelona, y se despachó por las estafetas para las demás ciudades y villas de Cataluña, y para las más principales de España, como Madrid, Toledo, Valladolid, Salamanca, Alcalá, Sevilla, Lisboa, Córdova, Granada, Valencia y Çaragoça, un cartel del tenor que se sigue... (cf. Rossich 2003: 92).

Així mateix, aquesta àmplia crida a la participació es va fer notar al certamen celebrat el 1614 a l'església del Patriarca San José dels carmelites descalços de Saragossa, per celebrar la mateixa efemèride. Luis Díez de Aux (participant també al certamen de 1614 de Barcelona) va realitzar-ne la relació impresa i, entre els versos que recull la narració, trobem dues composicions de Graïda (o Agraïda) Grimau de Llupià, dedicades a lloar les qualitats i dons de la carmelita: un sonet i una glosa. Pel que fa al sonet, més enllà de la lloança hiperbòlica de rigor, hi llegim una referència a l'episodi del clau proporcionat per Jesucrist a la religiosa com a dàdiva divina, per tal com el cartell del setè certamen al qual fou presentat, establia prèviament aquest tema (Díez de Aux 1615: 9) procedent d'un passatge del Libro de la vida teresià (cap. 39, \ 1) ${ }^{.55}$

53 BUB, Opúsculos espirituales de los padres José de S. Francisco y Juan de Jesús María, Ms. 1113, f. 365-366v.

54 BUB, Opúsculos espirituales...f. 373v-374.

55 «Estando yo una vez importunando al Señor mucho porque diese vista a una persona que yo tenía obligación, que la había del todo casi perdido, yo teníale gran lástima y temía por mis pecados no me había el Señor de oír. Aparecióme como otras veces y comenzóme a mostrar la llaga de la mano izquierda, y con la otra sacaba un clavo grande que en ella tenía metido. Parecíame que a vuelta del clavo sacaba la carne. Veíase bien el gran dolor, que me lastimaba mucho, y díjome que quien aquello había pasado por mí, que no dudase sino que mejor haría lo que le pidiese; que El me prometía que ninguna cosa le pidiese que no la hiciese, que ya sabía El que yo no pediría sino conforme a su gloria, y que así haría esto que ahora pedía; que aun cuando no le servía, mirase yo que no le había pedido cosa que no la hiciese mejor que yo lo sabía pedir, que cuán mejor lo haría ahora que sabía le amaba, que no dudase de esto». 
Verònica Zaragoza Gómez. «Cual doctora en cielo graduada... ». La poesia femenina per als certàmens literaris amb motiu de la beatificació i canonització de Teresa de Jesús (València, 1614 i 1621; Barcelona, 1614)

Más que a su madre quiso aventajaraos

pues en Josef le entrega a ella esposo

y Dios, en Dios a vos por solo honraros.

12

El clavo que os ha dado tan costoso

por arras y señal que pudo amaros

ponedle a la fortuna victorioso.

[...](Díez de Aux 1615: 86)

Pel que fa a la glossa de Graïda, destaca la consideració de Teresa de Jesús com a «Apolo divino» i com a «profeta»:

Es un Apolo divino
la que va a pisar el cielo,

un profeta, pues convino
serlo para dar al suelo
fruto que es fruto divino.
Es felicísima madre
con hijos sin tener padre,
siendo virgen en efeto
el ser madre en un sujeto
no ballo santa a quien le cuadre.
[...](Díez de Aux 1615: 98-99)

La noblesa de l'autora dels versos, Graïda de Grimau, i el seu art en la versificació són motiu de lloança en la sentència del certamen. Tot i així, per a la primera peça, s'hi considera que l'accent català de l'autora l'hauria feta errar:

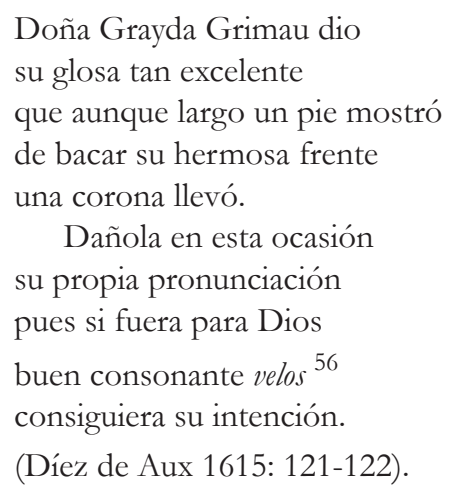

Per al segon text, tot i que hi apareix com a una poeta destra, la sentència aclareix que Graïda no ha rebut el premi perquè ha comés alguns errors de rima:

$56 \mathrm{Al}$ ludeix a la pronúncia de 'veloz', a la catalana, que apareix transcrit com a «velos» al poema de Graïda. 
Verònica Zaragoza Gómez. «Cual doctora en cielo graduada... ». La poesia femenina per als certàmens literaris amb motiu de la beatificació i canonització de Teresa de Jesús (València, 1614 i 1621; Barcelona, 1614)

\author{
Doña Grayda Grimau sabe \\ hazer versos con destreza \\ y con estilo harto grave \\ honronos con su nobleza, \\ y es bien su ingenio se alabe. \\ El premio no se le da \\ porque advertido no ha \\ que allí donde dize el suelo \\ por consonante de buelo \\ puso un $e$ que ha de ser $a$. \\ (Díez de Aux 1615: 121-122).
}

Més enllà d'aquestes peces que ens han arribat, sabem que Graïda també va escriure un romanç per al novè certamen, perquè apareix citada a la sentència com a «moradora del Parnàs» per una peça no conservada:

\author{
Doña Grayda Grimau queda \\ moradora del Parnaso \\ y es bien que se le conceda, \\ pues ni escrive ni da paso \\ donde a sus ninfas no exceda. \\ $\mathrm{Y}$ aviendo hallá de morar, \\ los premios le han de sobrar \\ y assí no es justo le demos \\ lo que le sobra, pues vemos \\ que honra y premios puede dar.
}

(Díez de Aux 1615: 134)

Sobre la identitat d'aquesta autora, ha estat identificada ${ }^{57}$ amb la mateixa que va escriure poesia laudatòria acompanyant els versos de la ja al ludida Anna Ivorra i Raset per a l’imprés Historia de S. Ramon de Peñafort (1603). Es tracta de Graïda (o Agraïda) Grimau de Llupià Vives i Xanxo (Barcelona, c. 1560-1614), filla de Francesc Jeroni de Grimau i de Vivers, donzell de Perpinyà, diputat del Braç Militar de la Generalitat de Catalunya i noble des de 1599 (Morales Roca 1995: 165), i d'Isabel de

\footnotetext{
57 Sabem que la religiosa barcelonina va morir el 1614, el mateix any en què Espanya sencera festejava l'efemèride de beatificació de la reformadora carmelita. Segons la relació de Diez de Aux, els festejos es van celebrar a l'octubre d'aquell mateix any i el dia quatre va tenir lloc la lectura dels versos del certamen, essent la data límit de lliurament de les peces el vint de setembre (Díez de Aux 1615: 10). El fet és que aquesta data es contradiria amb la data de defunció documentada de la religiosa: el 3 d'agost del dit any; amb tot, des que la notícia de beatificació havia arribat a la Península (i, evidentment, Barcelona fou un dels primers llocs a assabentar-se'n, atés que les noves arribaven per mar), podria ser que Graïda ja tingués escrits els seus poemes i que els enviés abans de morir, quan just faltava un mes per tancar-se la recepció dels versos; de fet, ens consta que altres participants també hi van enviar els seus poemes prèviament. La qualitat artística de Graïda i la seva experiència amb la versificació és una bona dada per no dubtar-ne de l'autoria. En aquest sentit, coincidim amb Mazuela-Anguita [en premsa].
} 
Verònica Zaragoza Gómez. «Cual doctora en cielo graduada... ». La poesia femenina per als certàmens literaris amb motiu de la beatificació i canonització de Teresa de Jesús (València, 1614 i 1621; Barcelona, 1614)

Llupià i Xanxo, de família de procuradors reials dels comtats del Rosselló i la Cerdanya. ${ }^{58}$ Del 1572, quan Graïla comptava uns huit o deu anys, data l'expedient de llinatge que se li va realitzar previ a l'ingrés al monestir de Santa Maria de Jonqueres de Barcelona,${ }^{59}$ de l'orde de Sant Jaume de l'Espasa (avui desaparegut) on va acabar professant $1586 .{ }^{60}$ Segons explica la historiadora de la comunitat, M. Mercè Costa (2005), aquest monestir va acollir les filles i esposes de militars de l'orde, que vivien normalment en família en habitacles propis sense renunciar als luxes inherents del seu estatus (algunes fins i tot tenien esclaves). En el moment de publicar la poesia laudatòria que hem esmentat més amunt, doncs, Graïda ja vivia al convent, tal com explicita la rúbrica (Moradell 1603: [f. 15]); en va esdevenir priora durant els anys 1609-1612 (Zaragoza Pascual 1997: 125) i, a diferència de tantes altres dones de la comunitat que n'eixien davant l'arranjament d'un bon casament, Graïda es va consagrar a la religió fins a la seva mort el 3 d'agost de 1614, ${ }^{61}$ sense descuidar, però, els aspectes intel lectuals i artístics. ${ }^{62}$ Gràcies a les recerques de efectuades per M. Ascensión Mazuela-Anguita ([en premsa] $)^{63}$ sobre la variada documentació del fons conventual conservat a l'Arxiu de la Corona d'Aragó i l'Arxiu Històric Nacional, sabem que tant Graïda com la seva germana Eugènia van exercir un important paper cultural com a directores del cor de la comunitat. De Graïda, a més, sabem que també es va dedicar a l'afer literari a través d'alguns poemes publicats en els espais de participació poètica més comuns a l'època: la poesia laudatòria i els certàmens barrocs.

\section{El certàmens amb motiu de la canonització de Teresa de Jesús (1621)}

El 1621, unes festes organitzades en honor a Teresa de Jesús van tornar a reunir de nou alguns dels poetes més reconeguts de la València del moment (Gaspar Aguilar, Francesc Aguilar, Marc Antoni Ortí, el carmelità fra Ambròs Roca de la Serna...), davant d’un públic que s’ho escoltava amb gran expectació:

58 Sobre el llinatge Grimau, veg. Lazerme (1972: I, 170-177) i, per a una història de la nissaga Llupià: Fernández, Catafau, Sales, Gifre, Pérez, Castán \& Sarobe (2006); i Fluvià (2004: 323).

59 Arxiu Històric Nacional (AHN), OM-RELIGIOSAS_SANTIAGO, Exp. 291. «Expediente de pruebas de Graida de Grimau de Lupiá Vives y Sancha, natural de Barcelona, para el ingreso como religiosa en el Convento Santa María de Junqueras de la Orden de Santiago» (1578).Alguns testimonis interrogats sobre el seu llinatge en l'esmentat expedient feren notar que tenia l'aspecte de comptar amb aquesta edat.

60 Segons consta al llibre de professions: ACA,ORM, Monacals-Universitat, Volums, vol. 164. Llibre abont estan escritas las señoras que han pres la creu, f. 3 (còpia realitzada el 1640 del llibre antic, iniciat el 1582, i continuada fins a 1787).

61 Així consta al llibre d’òbits de la comunitat, recopilat el 1699, amb anotacions del segle xIV i que s'allarga fins al segle XVIII: ACA, ORM, Monacals-Universitat, Volums, vol. 165, Llibre de obits de las senyoras de la Real Casa de Nostra Senyora de Junqueres de Barna... y de algunas personas de llur familia, com y tambe de alguns devots y benefactors.

62 Sobre l'activitat cultural d'aquesta comunitat, havia evidenciat Costa que: «Els interessos culturals eren, per força, variadíssims. Si no totes, una gran part de les monges sabia llegir. Els llibres eren especialment de caràcter religiós però també n'hi havia d'altres menes, com per exemple, llibres de faules. D'escriure potser en sabien una mica menys, vistes les signatures d'elles en alguns llibres dels arxius. El segle XVII, algunes monges posseïen un escriptori. Una d'elles, Teresa d'Erill, fou coneguda per les seves poesies. N'hi havia que tenien aficions musicals: Agraïda Grimau (m. 1614) tenia una arpa i un monocordi» (2005: 44).

63 Agraïm a l'autora que ens haja permès la seva lectura abans de publicar-lo. 
Verònica Zaragoza Gómez. «Cual doctora en cielo graduada... ». La poesia femenina per als certàmens literaris amb motiu de la beatificació i canonització de Teresa de Jesús (València, 1614 i 1621; Barcelona, 1614)

\begin{abstract}
Huvo tan grande concurso de gente a ver el Certamen Poético, que algunos soldados de la guarda del Virrey que estavan prevenidos para oponerse a la furia del pueblo, apenas pudieron hazerle resistencia; y assí para que huviesse tiempo para todo, començaron las Vísperas muy temprano, y no fue parte el alboroto de la gente, para que no fuessen muy solemnes (cf. Mas i Usó 2009: 216).
\end{abstract}

La imminent arribada de la notícia de canonització de la beata, que vindria el 12 de març de l'any següent va comportar é la celebració del corresponent certamen, que va tenir com a escenari el convent de Nostra Senyora del Carme de la ciutat. ${ }^{64}$ En coneixem els detalls a través de la relació impresa de fra Manuel Mendoça, editada a València el $1622 .{ }^{65}$ Foren convocats tres premis explicitats pel cartell (Mendoça 1622: 37-39): el primer anava dedicat al famosíssim episodi de la transverberació de la carmelita, narrada en veu pròpia a la seva Vida (Libro de la Vida, Cap. 29, \13) i immortalitzada en marbre per l'escultor Gian Lorenzo Bernini molt poc després de la canonització (entre 1647 i 1652); el segon, al passatge comentat més amunt sobre el clau regalat per Crist a Teresa de Jesús. I, el tercer, al carmelita anglès Simon Stock (Aylesford, c. 1165 - Bordeus, 1265), eremita venerat com a sant, al qual, segons la llegenda coneguda, la Mare de Déu li hauria regalat l'escapulari carmelita.Entre els trenta-un poetes participants esmentats al vexamen (Ferrando 1983: 941), s'hi recompten cinc noms femenins, ${ }^{66}$ però d'aquestes només ens han arribat tres de les composicions, recollides per Mendoça. La majoria de les autores són religioses: parlem de la franciscana sor Emerenciana d'Aro, autora d'unes dècimes castellanes presentades al segon certamen, dedicades al clau diví regalat a la carmelita:

32

36

40
En arras un clavo fuerte os da el Esposo y con él palabra de seros fiel hasta después de la muerte; que entonces será la suerte que jamás temerá alguna adversidad importuna pues que de su mano queda clavado siempre en la rueda de vuestra buena fortuna. [...](Mendoça 1622: 76-78)

64 Una descripció del certamen a Ferrando (1983: 941-953); Carreres Zacarés (1925: II, 244-247); Mas i Usó (2009: 215-225); i Romera (1982a).

65 S'ha considerat que aquest certamen es va celebrar en el context de les festes de canonització (p.e. al citat article de Vicent J. Escartí, «Festes valencianes a santa Teresa (1614 i 1622)»), però no fou així, ja que per quan es va celebrar el certamen (fou convocat per el 28 d'octubre de 1621), la notícia encara no havia arribat i la canonització encara trigaria uns mesos; seguim en aquest aspecte Mas i Usó (2009: 215-225).

66 Romera (1982a: 208); i Ferrando (1983: 942) al ludeixen a aquestes dones.

SCRIPTA, Revista internacional de literatura i cultura medieval i moderna, núm. 6 / desembre 2015 / pp. 251 - 290 
Verònica Zaragoza Gómez. «Cual doctora en cielo graduada... ». La poesia femenina per als certàmens literaris amb motiu de la beatificació i canonització de Teresa de Jesús (València, 1614 i 1621; Barcelona, 1614)

D’aquesta autora només se sap que pertanyia a les clarisses per la rúbrica de la composició i per una menció al vexamen:

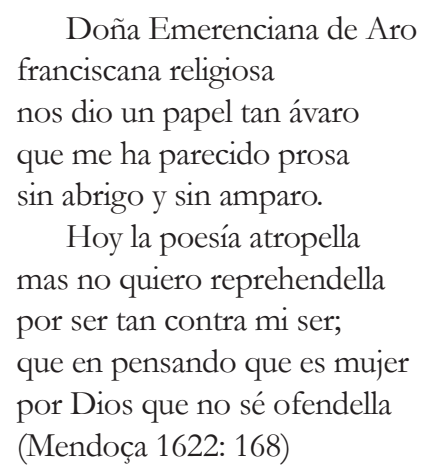

Després d'aquesta, sor Eugènia Pérez (de qui només sabem que va viure al convent de carmelites calçades de la Puríssima Sang de Crist d'Ontinyent), ${ }^{67}$ va aportar a la devoció un sonet dedicat al dard diví de «luz radiante» que va traspassar el cor de Teresa:

El sacro Esposo, verdadero amante,
preso de vero amor, Teresa hermosa,
por mostrar que os estima como esposa
finezas hace de amador constante.
Un dardo envía de su luz radiante
flechado al pecho porque seáis dichosa,
pues quedáis de su herida tan gloriosa
que quisierais heridas cada instante.
Si amor os facilita el golpe fuerte,
gusto os dará el dolor, salud la herida,
juzgando su rigor a feliz suerte,
pues partida quedáis con Dios unida,
y aun si el golpe que os da fuera de muerte
dierais por él mil veces vuestra vida.
(Mendoça 1622: 214)

Però, sens dubte, entre aquests noms, destaca el de la cistercenca sor Bernarda Romero (València, a. 1592-1621), coneguda popularment com Na Romera. En certa manera, el silenci documental al voltant d'aquesta autora contrasta amb el ressò que degué assolir en l'ambient dels certàmens valencians: poeta assídua en aquests esdeveniments socioliteraris des de finals del segle XvI (Ferrando 1983: 882, 900, 904-906, 917, 919, 923, 933 i 942), ${ }^{68}$ devia de ser ben coneguda pel públic assistent.

67 Caldria esbrinar quin tipus de relació té amb Jeroni Pérez, un altre participant del mateix certamen.

68 I és que, tal com denunciava Martí i Grajales, es té molt poca informació biogràfica sobre aquesta autora, tot i la seva prolífica activitat en certàmens (1927: 411-412). 
Verònica Zaragoza Gómez. «Cual doctora en cielo graduada... ». La poesia femenina per als certàmens literaris amb motiu de la beatificació i canonització de Teresa de Jesús (València, 1614 i 1621; Barcelona, 1614)

En aquesta ocasió, hi va participar amb un romanç castellà presentat a la devoció de la futura canonitzada. Mereix la pena reproduir-lo sencer pel to personal que reflecteixen els versos:

El cielo santo os alabe,

Teresa divina y santa,

que la tierra es imposible

4

decir vuestras alabanzas,

pues los más raros ingenios

de naturaleza humana

no podrán daros alcance

8 por ser prodigiosa y rara.

Aunque serán más que raros

los que hoy en vuestra alabanza

podrán arrancar las Musas

12 de las alas de la Fama;

mas yo, que me reconozco

por mucho menos que nada,

atreverme no podré:

16 ténganme por escusada.

Que el privilegio y virtudes

que os perficionan y esmaltan

son de número infinito

20 y nadie podrá explicallas.

Los angélicos ingenios

que os tienen allá en su patria

con cánticos de alegría

24 eternamente os alaban;

y estos señores ilustres

que en esta ocasión me mandan

haga cosas imposibles

28 habrán de suplir mis faltas.

Y mi padre san Bernardo, que tuvo dicha tan alta, me haga participante

32 de aquella leche sagrada, pues tiene tanta virtud que sola una gota basta aunque de su labio al mío

36 hay infinita distancia.

Para decir que sois vos,

Teresa, tan rica planta que dais $\tan$ heroico fruto

40 que al gusto de Dios agrada.

Sois jardín fresco y hermoso,

sois la huerta soberana

donde el Hortelano eterno,

44 se recrea y se regala.

Sois la fuente manantial

de tan cristalinas aguas

que con su risa producen

48 número de flores tantas,

SCRIPTA, Revista internacional de literatura i cultura medieval i moderna, núm. 6 / desembre 2015 / pp. 251 - 290 
Verònica Zaragoza Gómez. «Cual doctora en cielo graduada... ». La poesia femenina per als certàmens literaris amb motiu de la beatificació i canonització de Teresa de Jesús (València, 1614 i 1621; Barcelona, 1614)

que al olfato del Esposo

infinitamente causan

más suavidad y contento

52 que los perfumes de Arabia.

Sois prado verde y ameno

de viva fe y esperanza

con que llegáis a alcanzar

56 allá laureola y palma.

Sois piedra la más preciosa

$\mathrm{y} \tan$ refulgente y clara,

cuanto de precio y valor

60 riquísima y estimada.

Perla la más oriental,

divinamente sacada

de la concha de la tierra

64 a los cielos transportada.

El Supremo lapidario

(por ser vuestra estima tanta)

en el nombre de Jesús

68 quiso fuerais engastada.

Sois la joya inestimable

$y$, en el arquimesa sacra

do Cristo tiene otras muchas,

72 la que más estima y guarda.

La sierva herida sois vos

que ese corazón traspasa

la flecha de amor ardiente

76 que os enciende en viva llama.

Sois la bella carmelita

de Dios querida y amada, que en señal de esposa suya

80 os da el anillo y las arras.

Sois entre las carmelitas patrona de las descalzas, alcanzad de vuestro Esposo

84 que sigan vuestras pisadas.

Sois el ave de rapiña

que con destreza y con gala

hacéis presa de los cielos

88 en la celestial morada;

sois el águila caudal

que con muy ligeras alas

dais el vuelo al consistorio

92 do hacéis nido y tomáis casa.

Pues en la corte del Rey

sois con el rey cortesana,

recaba para Valencia

96 mercedes y muy colmadas.

Peregrina sois en bienes,

poderosa, rica y basta,

condoleos desta Romera

100 que vive necesitada.

(Mendoça 1622: 196-201)

SCRIPTA, Revista internacional de literatura i cultura medieval i moderna, núm. 6 / desembre 2015 / pp. 251 - 290 
Verònica Zaragoza Gómez. «Cual doctora en cielo graduada... ». La poesia femenina per als certàmens literaris amb motiu de la beatificació i canonització de Teresa de Jesús (València, 1614 i 1621; Barcelona, 1614)

Tot amb tot, les paraules amb què apareix citada al vexamen no la deixen gaire ben parada:

\author{
De sor Bernarda Romero \\ he visto un largo romance \\ mas ofenderla no espero, \\ aunque es, si hablo en buen romance, \\ romance de romancero. \\ Después que el suceso aguardo \\ honra desta religión, \\ hallé un descuido gallardo \\ pues por loar a Simón \\ nos alaba a San Bernardo. \\ Pues fue tan poco avisada \\ en la presente ocasión, \\ a su pluma mal cortada \\ prémiela su religión, \\ que ésta no le debe nada. \\ (Mendoça 1622: 164)
}

I ja per anar acabant, a través del vexamen ens han arribat el nom d'altres dues dones que van presentar els seus versos per a l'ocasió, però que no foren recollits en la relació de Mendoça. ${ }^{69}$ Parlem de la carmelita sor Felicitas Amada ${ }^{70}$ i de «doña Laura», lloada pel fet que «a muchos hombres excede» amb la seva obra:

\footnotetext{
Sor Felicitas Amada un grave yerro confiesa, pues nos ha dado turbada naturaleza, y Teresa, consonancia mal mirada.

Por lo carmelita hermana destos Padres viene a ser y es mi hermana, más no gana, aunque para no perder, novenas hizo a Santa Ana. (Mendoça 1622: 165)

$[\ldots]$

Doña Laura celebrada a muchos hombres excede con su pluma bien cortada, y pésame que no quede siendo Laura laureada.
}

69 Tal com reconeix l'autor del llibre, s'hi van llegir d'altres més poemes que tampoc no figuren al llibre.

70 Per aquesta mateixa raó, Romera (1982) no les cita.

SCRIPTA, Revista internacional de literatura i cultura medieval i moderna, núm. 6 / desembre 2015 / pp. 251 - 290 


\author{
Dos versos largos abarca \\ su papel, si bien lucido, \\ pero poética parca \\ hoy no la hubiera ofendido \\ si fuera yo su petrarca. \\ (Mendoça 1622: 163)
}

\title{
3. Conclusions
}

Pel que fa a la poesia de certamen femenina que acabem de revisar, ens ha interessat remarcar les imatges que aquestes autores de l'àmbit català proporcionen sobre l'obra i la vida de Teresa de Jesús, que es consolida com a mestra d'esperit i de ploma durant el segle XVII; gran figura espiritual $\mathrm{i}$ intel lectual que va esperonar les seves congèneres a empunyar la ploma en una època en què les circumstàncies socioculturals no resultaven gaire propícies per a l'escriptura femenina. ${ }^{71} \mathrm{Si}$ bé és cert que la llista de poetes participants en aquests certàmens organitzats a l'entorn de la figura de Teresa de Jesús representa una xifra reduïda i secundària, en relació amb el predomini dels homes participants, tanmateix ens resulta reveladora quant a l'evolució de l'escriptura femenina. I és que, amb la concurrència de dones als certàmens, comencen a participar en una representació teatral social simbòlica que els permetia assumir un paper creador actiu, que fora d'aquest escenari festiu rarament encarnaven (almenys públicament). I, de retruc, aquest rol actiu assumit en aquests esdeveniments festius i literaris, més enllà de presentar-les com a meres espectadores, podia servir-los per projectar-se un cert prestigi social i contribuir, d'alguna manera, a la visibilitat de l'escriptura femenina pública. Especialment, en aquest punt d'inflexió que va suposar l'any 16141615, tot coincidint amb el pic de concurrència femenina en els certàmens peninsulars dedicats a la beatificació de Teresa de Jesús (Baranda 2005: 219). Caldrà seguir treballant-hi.

71 Remetem a l'estudi fonamental de Nieves Baranda (2005) i, en relació a l’àmbit lingüístic català, al monogràfic publicat en aquesta mateixa revista el 2013 (Zaragoza coord. 2013). 
Verònica Zaragoza Gómez. «Cual doctora en cielo graduada... ». La poesia femenina per als certàmens literaris amb motiu de la beatificació i canonització de Teresa de Jesús (València, 1614 i 1621; Barcelona, 1614)

\section{Bibliografia}

Ahumada, E. (ed.) (2003) Epistolaris d'Hipòlita Roís de Liori i d'Estefania de Requesens (segle xvi), València: PUV.

Alenda y Mira, J. (1903) Relaciones de solemnidades y fiestas públicas de España, Madrid: Sucesores de Rivadeneyra.

Amelang, A. (2005): «Autobiografías femeninas», dins I. Morant (dir.), Historia de las mujeres en España y América Latina. Vol. II. El mundo moderno, Madrid: Cátedra, 155-168.

Arenal, E. \& Schlau, S. (1989) «Leyendo yo y escribiendo ella. The convent as Intellectual community», Journal of Hispanic Philology, 13/3, 214- 229.

Baranda, N. (2005) Cortejo a lo probibido. Lectoras y escritoras en la España moderna, Madrid: Arco/Libros. - (2014) «Yo soy así y así me he construido. El poder de la voz autobiográfica femenina en la Edad Moderna hispana», Guaraguao, 18/47, 19-42.

Beltran Larroya, G. (1964) «Las obras de santa Teresa de Jesús publicadas en Barcelona (15881961)», Monte Carmelo, 72, 223-268.

Blanco, M. (1986) «Arquitecturas efímeras, ornatos y máscaras. El lugar y la teatralidad de la fiesta barroca», dins J. Ma Díez Borque (comp.), Teatro y fiesta en el Barroco. España e Iberoamérica, Barcelona: Serbal, 41-70.

—. (1988) «La oralidad en las justas poéticas», Edad de Oro, 7, 33-47.

Blecua, A. \& Serés, G. (2008) La Edición del teatro de Lope de Vega: las Partes de comedias: criterios de edición, Bellaterra: Grupo de Investigación Prolope, Universitat Autònoma de Barcelona.

Bolufer, M. (2009) «Desde la periferia. Mujeres de la Ilustración 'en province’», dins R. de la Calle, (ed.), La Real Academia de Bellas Artes de San Carlos en la Valencia ilustrada, València: PUV, 67-100.

Carreres Zacarés, S. (1926) Ensayo de una bibliografía de los libros de fiestas celebrados en Valencia y su antiguo reino, València: Sucesores de Rivadeneyra.

Carreres de Calatayud, F. (1949) Las fiestas valencianas y su expresión poética, (siglos xvi-xviii), Madrid: CSIC.

Collell, A. 1955: Un capitol d'història vigatana. Fundació del convent de les monges dominiques de Santa Clara, Vic: Editorial Sala.

Corbera, E. (1629) Vida y echos maravillosos de dona Maria de Cervellón. Barcelona: Pere Lacavalleria.

Costa, M.M. (2005), El món de les dames de Jonqueres, Lleida: Pagès Editors.

Dalmau, J. (1615) Relación de la solemnidad con que se han celebrado en la ciudad de Barcelona las fiestas a la beatificación de la madre S. Teresa de Jesús [...], Barcelona: Sebastián Matevad.

Diego de San José 1615: Compendio de las solenes fiestas que en toda España se bicieron en la Beatificación de N. B. M. Teresa de Jesús, Madrid: Viuda de Alonso Martín.

SCRIPTA, Revista internacional de literatura i cultura medieval i moderna, núm. 6 / desembre 2015 / pp. 251 - 290 
Verònica Zaragoza Gómez. «Cual doctora en cielo graduada... ». La poesia femenina per als certàmens literaris amb motiu de la beatificació i canonització de Teresa de Jesús (València, 1614 i 1621; Barcelona, 1614)

Díez de Aux, L. (1615) Retrato de las fiestas que a la beatificación de la bienaventurada Virgen y Madre Teresa de Jesús, renovadora de la Religión primitiva del Carmelo... Saragossa: Juan de Lanaja y Cuartanet.

Ettinghausen, H. (2010) «Barcelona, centre mediàtic del segle xvii i les seves relacions de festes», dins Festes i celebracions. Barcelona, 1700, Barcelona: Ajuntament de Barcelona. Institut de Cultura (Ciutat del Born. Barcelona 1700, 4), 196-275.

Fernández, J., Catafau, A., Sales, N., Gifre, P., Pérez, M., Castán, A. \& Sarobe, R. (2006) Història dels Llupià (1088-1771) $i$ dels seus llinatges incorporats: Icard, Roger $i$ Vallseca, Canet: Trabucaire.

Ferrando, A. (1983) Els certàmens poètics valencians del segle XIV al XIX, València: Alfons el Magnànim.

Gras, M. (2013) «Patronatge femení i fundació de convents. El convent de la Immaculada Concepció de Barcelona (1589)», dins B. Garí (ed.), Redes femeninas de promoción espiritual/Women's Networks o spiritual Promotion, Roma: IRCVM-Medieval Cultures I-II, Viella (Ircum-Medieval Cultures, 2), 251-265.

Gregori, R.M. (2012) La impresora Jerònima Galés i els Mey (València, segle xvi), València: Biblioteca Valenciana.

Herpoel, S. (1999) A la zaga de Santa Teresa: autobiografias por mandato, Àmsterdam: Rodopi.

Jude, V. (2012) «Edición postuma y legitimación de los textos de Teresa de Jesús», dins A. Cayuela \& R. Chartier (coord.), Edición y literatura en España (Siglos xviy xvii), Saragossa: Prensas Universitarias de Zaragoza, 41-58.

Herrero, M.A. (2009) Lletraferides modernes: catàleg de les escriptores valencianes dels segles xvii-xviii, Sant Vicent del Raspeig: Centre d'Estudis sobre la Dona, Universitat d'Alacant.

Lazerme, P. (1975-1977) Noblesa catalana: cavallers i burgesos honrats de Rosselló i Cerdanya, 2 vol., La Roche-sur-yon: Impr. centrale de l'ouest.

Llamas, E. (OCD) (1972) Santa Teresa de Jesús y la Inquisición española, Madrid: CSIC.

Manero, P. (1999), «Las relaciones de las Solemnes fiestas que en toda España se hicieron en la beatificación de la N. B. M. Teresa de Jesús de Diego de San José», dins S. López \& N. Pena (ed.), La fiesta. Actas del II Seminario de Relaciones de Sucesos (A Cornña, 13-15 de julio de 1998), Ferrol: Sociedad de Cultura Valle Inclán, 223-234.

Marín, M.C. (2013) «Los certámenes poéticos aragoneses del siglo xvii como espacio literario de sociabilidad femenina», Bulletin Hispanique, 115 /1, 145-164.

—. [en premsa]: «Fuera del convento: las monjas en las justas aragonesas del siglo xvii», Destiempos.

Martí, J.M., Castro, R. \& Coloma, A. (1987) Els "josepets". Parròquia de la Verge de Gràcia i Sant Josep. 300 anys d'història, Barcelona: Arxiu Diocesà / Akribos Edicions.

Martí i Ascó, M. (2004 [2013]) «Cultura literària de la dona en la València dels segles xvi i xvii», dins Escriptors valencians de l'Edat Moderna, València: Acadèmia Valenciana de la Llengua, 121-137 [reed. Scripta, 1/1 [=L'escriptura en femení a les terres de llengua catalana (segles xvi-xviii)], 36238 [el citem a través de la versió més recent]. 
Verònica Zaragoza Gómez. «Cual doctora en cielo graduada... ». La poesia femenina per als certàmens literaris amb motiu de la beatificació i canonització de Teresa de Jesús (València, 1614 i 1621; Barcelona, 1614)

Mas Arrondo, A (1997) «Acerca de los escritos autógrafos teresianos: Vida, Castillo interior y Relaciones», dins S. Ros García (coord.), La recepción de los místicos Teresa de Jesús y Juan de la Cruz, Salamanca: Universidad Pontificia, 81-134.

Mas i Usó, P. (2009) Justas valencianas barrocas, València: Biblioteca Valenciana.

Martí Grajales, F. (1927) Ensayo de un diccionario biográfico y bibliográfico de los poetas que florecieron en el Reino de Valencia hasta el año 1700, Madrid: Revista de Archivos, Bibliotecas y Museos.

Mazuela-Anguita, A. [en premsa b] «La vida musical en el monasterio de Santa Maria de Jonqueres en los siglos XVI y XVII: Agraïda y Eugènia Grimau», Revista Catalana de Musicologia.

Mendoça, M. (1622) Fiestas que el convento de nuestra Señora del Carmen de Valencia bizo a nuestra Santa Madre Teresa de Jesús, a 28 de Octubre, 1621, València: Felipe Mey.

Mínguez, V., González, P. \& Rodríguez, I. (2010) La Fiesta Barroca. El Reino de Valencia (1599-1802), Castelló de la Plana: Universitat Jaume I.

Moradell, V.M (1603) Historia de S. Ramón de Peñafort, frayle de Predicadores en coplas Castellanas... Barcelona: Sebastià de Cormellas.

Morales Roca, F. (1995) Ciudadanos y burgueses honrados habilitados como sindicos del brazo real en las Cortes del Principado de Cataluña. Dinastias de Trastamara y de Austria. Siglos xv y xvi (1410-1599), Madrid: Hidalguia.

Narváez, C. (1994) «Josep Dalmau, promotor dels convents de carmelites descalços de Barcelona», Analecta Sacra Tarraconensis, 67 / 1, 589-598.

—_. (2004)_El tracista fra Josep de la Concepció (1626-1690), Barcelona: PAM.

Pedraza, P. (1982) Barroco efímero en Valencia, València: Ajuntament de València.

Rebullosa, J. (1601) Relación de las grandes fiestas que en esta ciudad de Barcelona se han echo, a la canonización de su bijo San Ramon de Peñafort..., Barcelona: Jaume Cendrat.

Romera, J.N. (1982) «Justas poéticas valencianas en honor de Santa Teresa», Letras de Deusto, 12 / 24, 199-216.

Rossich, A. (2003) «Els certàmens literaris a Barcelona, segles xiv- xviii», Quaderns d'Història, 9, 83108.

- (2006) «Els Certàmens: de la Gaia Ciència als Jocs Florals», dins S. Martí (coord.) et al., Actes del Tretzè Col loqui Internacional de Llengua i Literatura Catalanes, Barcelona: Associació Internacional de Llengua i Literatura Catalanes /PAM, 63-90.

Rubió, J. (1984-1986) Història de la literatura catalana, vol. II, Barcelona: Departament de Cultura de la Generalitat de Catalunya.

Schlau. S. (2002) «Following Saint Teresa: Early Modern Women and Religious Authority», Modern Language Notes, 117/2, 286-309.

SCRIPTA, Revista internacional de literatura i cultura medieval i moderna, núm. 6 / desembre 2015 / pp. 251 - 290 ISSN: 2340-4841 · doi:10.7203/SCRIPTA.6.7832 
Verònica Zaragoza Gómez. «Cual doctora en cielo graduada... ». La poesia femenina per als certàmens literaris amb motiu de la beatificació i canonització de Teresa de Jesús (València, 1614 i 1621; Barcelona, 1614)

Tomás de la Cruz (OCD) (1961a) «Los 'Avisos’ de Santa Teresa de Jesús», Ephemerides Carmeliticae, $12,320-355$.

—. (1961b) «Autor y antecedentes de los 'Avisos de la Madre Teresa de Jesús'», El Monte Carmelo, 69, 391-418,

— - (1963) «Avisos espurios y Avisos genuinos: en diálogo con los PP. Efrén y Otger y con el P. A. Huerga», Ephemerides Carmeliticae, 13, 576-616.

Thompson, I. (2008) «La cuestión de la autoridad en la controversia sobre el Patronato de santa Teresa de Jesús», dins F.J. Aranda Pérez \& J.D. Rodrigues (ed.), De Re Publica Hispaniae: una vindicación de la cultura politica en los reinos ibéricos en la primera modernidad, Madrid: Silex, 293-320.

Trueblood, A. (1977) «La mariposa y la llama: motivo poético del Siglo de Oro», dins F. López, J. Pérez, N. Salomon \& M. Chevalier (coord.), Actas del Quinto Congreso Internacional de Hispanistas, vol. 2, Bordeus: Instituto de Estudios Ibéricos e Iberoamericanos. Universite de Bordeaux III, 829-837.

Vincent-Cassy, C. (2010) «Los santos, la poesía y la patria», Jerónimo Zurita, 85 [=Fábrica de santos: España, siglos xvi- xvii], 75-94.

Zaragoza, V. (coord.) (2013), «L'escriptura en femení a les terres de llengua catalana (segles xvixviii)», Scripta: revista internacional de literatura $i$ cultura medieval i moderna, 1 [https://ojs.uv.es/index. $\mathrm{php} /$ scripta/issue/view/191/showToc]

. [en premsa] «Sapientia absconsa et thesaurus invisus. Notes sobre la presència femenina en les premses rosselloneses (ss. xvi-xviii)», Butlletí de la Reial Acadèmia de Bones Lletres de Barcelona.

Zaragoza Pascual, E. (1997) Catàleg dels monestirs catalans, Barcelona: PAM.

SCRIPTA, Revista internacional de literatura i cultura medieval i moderna, núm. 6 / desembre 2015 / pp. 251 - 290 